\title{
4
}

\section{Three Endogenous Economic Crises since the Reform and Corresponding Resolutions 1978-1997}

According to the authoritative and official phase-demarcation put forward by former President Hu Jintao, China has entered the "intermediate phase of industrialization" at the turn of the twenty-first century. The development path of industrial countries in general shows that the intermediate stage may be further divided into the stages of "industrial capital structural adjustment" and then "global industrial capital configuration adjustment as well as expansion". These are inevitable stages that follow the completion of primitive accumulation for industrialization. During this phase, the scope of flow and integration of production factors as well as the extent of institutional transition costs transfer would both expand significantly.

Within this intermediate phase of industrialization, that is, from 1978 when the Reform and Opening-Up started to 1997 when the Asian Financial Crisis broke out during which industrial capital structural adjustment occurred, China experienced three economic crises. Chronologically these would be the 5th, 6th and 7th crises in the seventy years of contemporary Chinese history since 1949. Furthermore, similar to the cyclical crises that took place during the "initial phase of 


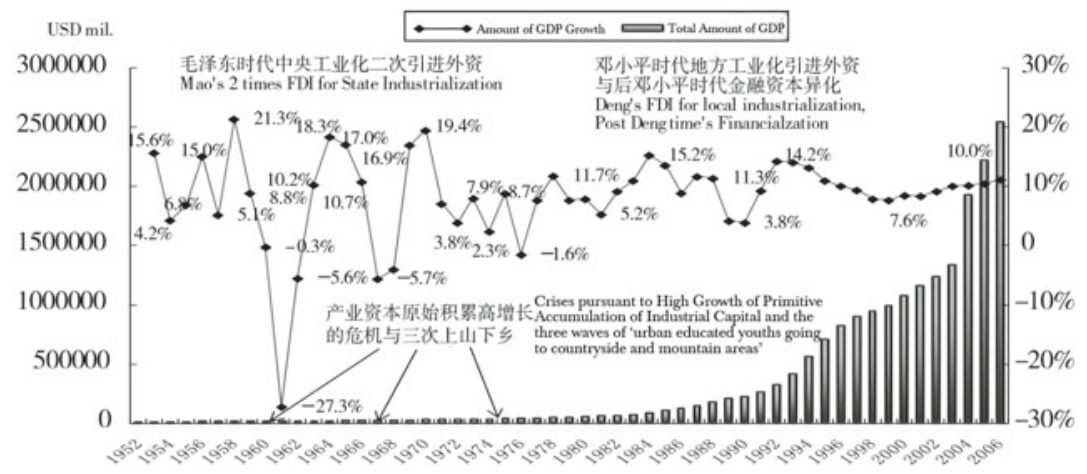

Fig. 1 China's Macro-economic growth and fluctuations 1952-2006

industrialization," the occurrence of all these three crises was mainly caused by domestic economic factors.

Under the constraints arising from the contradiction within the urban-rural dichotomy - the fundamental institution in China-a series of rural reforms, such as rural "de-organization" and marketization of produce, implied that it was no longer possible to make use of the organization of rural collectivization to absorb unemployed urban laborers, nor to extract more surplus from the sannong. As a result, except for the 5 th crisis in early 1980 s during which the launch of rural reforms had facilitated urban economic recovery, both the 6th in 1988-1989 and the 7th in 1993-1994 were forced to take hard-landing in urban sector, in turn causing significant negative impact on the sannong.

Another aspect was similar to the general experience of countries and regions that have already formed a complete industrial capital structure. The amplitudes of economic fluctuations in China during these three occasions that took place in the intermediate phase of industrialization had notably narrowed. China was still able to sustain a growth amid the institutional transition with "Chinese characteristics". (Fig. 1 shows year by year economic fluctuations since the establishment of New China.)

After mid-1990s, China was integrated into the international economic system. Its macro-economic fluctuations became increasingly aligned with the global macro-economic cycle. To some extent it led to the situation that since 1997, Chinese government had to face "imported" (exogenous) crises. The crisis in 1998 was induced by the 


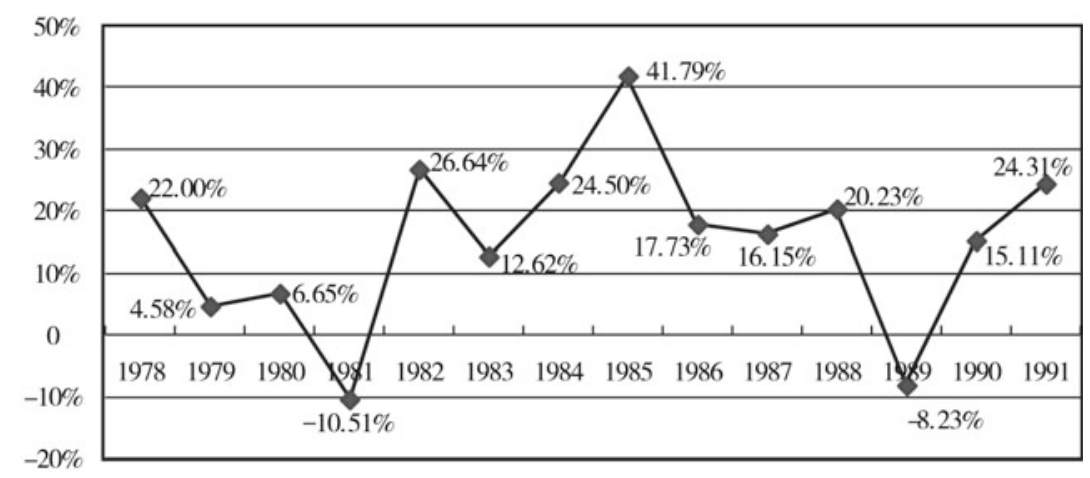

Fig. 2 Growth rate in total fixed investments by state-owned units 1978-1991 (Data source: China Statistical Yearbooks)

Asian financial crisis and the 2009 crisis was caused by the Wall Street financial crisis in 2008. Both of these led to drastic declines in overseas demand. Therefore, the "bailout" measures taken by the government responding to external factors were quite different from the austerity measures adopted during the previous six crises. We will discuss these two exogenous crises in Chapter 5.

The curve in the diagram showed that during the "intermediate phase of industrialization", the gap between the eruptions of the 5th (1980) and 6th (1988) crisis was 7-8 years. Back then the economy was still mainly state-owned/operated, and investments were largely government funded. In both cases the macro-regulation measures adopted by the government were similar, which meant cutting the scale of investments, hence the large declines in the investment growth rates- $10.51 \%$ in $1981,8.23 \%$ in 1989 , in turn leading to faster decline of the macro-economy (Fig. 2).

However, the economic crisis led to the 1989 Tiananmen incident and what followed was the second blockade of China by the West (the first blockade had been lifted in 1971), accompanied by the clamors of "China collapse". After that, what happened in early 1990s was a strong push to accelerate economic reform, with deepening marketization and financialization, as well as Deng Xiaoping's "Southern Inspection Speech" which was in complete opposition to the previously effective austerity policy. The main contents of these policies were the conces- 
sions to local authorities to empower their autonomy to expand the scale of attracting investment and directly take the gains from local resource capitalization. It could be seen as a bargain for the political support from local governments to consolidate the second generation core collective leadership of the central. Compared to the formation of the first generation core collective leadership through revolution, this process eventually strengthened the authority and legitimacy of China's new centralized system. Its direct institutional costs might indeed have been reduced but people seldom raised the issue of indirect costs. Judging from what actually happened afterwards, one of the indirect costs might be a shorter gap between crises, from 7 to 8 years as was the case between 1988 and 1993-1994 to once every 5 years afterwards.

Among the economic activities launched in the name of "market economy" in 1992 on the 14th National Congress by the CPC Central Committee, the main and most substantive one showed in the form of local authorities' autonomy to drive forward government corporatism by drawing support from Deng's Southern Inspection Speech, which eventually gave rise to economic overheating and had the central government take the liabilities for foreign debt. The central government did not have a sufficient share of the fiscal revenues to bear that cost. Therefore it had no option but to accelerate monetization-money printing machines operated round the clock to increase money supply in large quantity. Simultaneously, three speculative markets: real estate, securities and futures, took the opportunity to liberalize, instantly attracting speculative funds from different walks of life in the society. Short-term investments grew aggressively and severe inflation emerged. Wherever speculative capital are building up within a short time span on a large scale, systematic economic risks intrinsic to it will intensify as a rule. China was no exemption. It rapidly triggered the economic crisis of 1993-1994, the substances of which were serious deficits in three major sectors directly controlled by the central government-fiscal, financial and balance of payments (Image 1).

With an economy overheating and at the same time encountering the three major deficits, the third plenary of the 14th Congress affirmed the line of "comprehensive reform". The Chinese government adopted in 1994 a stop-loss approach and introduced austerity measures that were 

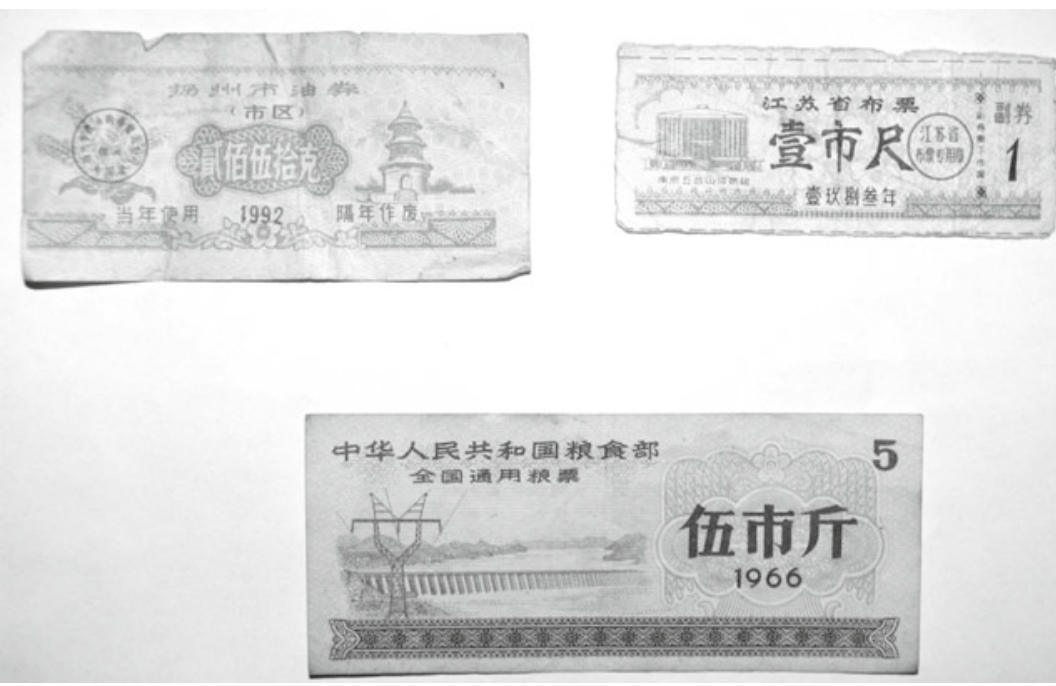

Image 1 In the 1950s to 1990s, China had issued various coupons for various consumer goods in specific periods. Back then, people had to have coupons in order to purchase corresponding goods. After the Reform and Opening-up, these coupons that witnessed the transformation of eras gradually faded out of people's lives

even broader and tougher than the ones later taken by the European Union in response to the European debt crisis. Major reforms in three realms were kick-started: the Renminbi devaluation, the marketization of foreign exchange by converging the official and market foreign exchange rates, and the Tax Division Reform between central and local governments. To supplement these, stringent macro-regulation measures were applied to tighten liquidity and land supply.

These three major measures were still limited to the regulation of resource flow. However, there were another two crucial and unprecedented measures related to the disposal of public assets: the government's retreat from two major aspects-from many state-owned enterprises (SOEs) and from public welfare provision. On the former, marketization reform of state-owned assets was launched. The government retreated from inefficient small and medium non-monopolized SOEs. Many SOEs would directly lay off workers, streamline operations and reduce headcounts to increase efficiency. On the latter, the SOEs introduced the 
marketization of staff housing accommodation (equivalent to the "public rental housing" in new pro-livelihood policy that has been a priority in recent years) as well as the commercialization of education, medical care and so on.

Eventually, after disposing of public assets stock at low prices in various ways, a large amount of non-performing debts were left on the books of banks and handed over to successors. After paying an enormous cost - tens of millions of workers laid off, tens of thousands of mass protest incidents, a decline in people's income resulting in weak domestic demands and so on-China finally achieved the so-called "soft-landing" in 1996.

Yet just when this successful soft-landing was announced by the media to the world, China had to face yet another setback due to the 19971998 Asian financial crisis which led to a decline in overseas demand. Instantly, with low demands both domestic and overseas, China became entrapped in a deflation lasting 3-4 years.

In the second half of the 1990s, given that China had already transformed to a growth model mainly relying on external demands and infra-structure investments, Chinese economy encountered the 8th economic crisis since its industrialization under the impact of external factors before it could fully recover from the previous one. That 8th crisis was also what this book refers to as the first imported (exogenous) economic crisis in contemporary China.

From the start of the Reform till the year 1997, the three crises (chronologically the 5th, 6th and 7th) had one thing in common, unlike the crises that had happened before-they could no longer directly transfer the costs to the sannong through government mobilizations and mandatory resettlement of surplus urban laborers on a large scale to the rural sector, which would then alleviate the unemployment pressure in cities. That was because after years of over-extracting agricultural surplus for urban industrialization, the sannong had become debilitated. Now as the urban sector became the state's main source of fiscal revenue, rural collectivization had completed its historical mission of serving the primitive accumulation of state capital. What followed was the government's retreat from the sannong that had no more surplus to extract from, with the household contract system. The state-organized rural collectivized 
economy then disintegrated and traditional peasant community that had been sustained for thousands of years now revived. The 200 million geographically and economically scattered peasant households could no longer accommodate surplus urban laborers on a large scale.

We attempt to point out the major differences between different policies in response to various crises. The rural reform which in fact constituted the retreat of the government from the non-profitable agricultural sector, brought institutional gains to the micro-economic realm with an active peasant economy and general increases in agricultural production. Yet in terms of the institutional costs in the macro-economy, it was manifested as "hard-landing" on urban sector whenever crisis took place hereafter.

In comparison, China begun to strengthen the investments into the debilitated sannong through the New Countryside Construction strategy since 2005. With the high profile "government re-entrance" into the agricultural sector, it was possible to again achieve a "soft-landing" in the 2008-2009 "imported" inflationary crisis, which relied on the rehabilitation of the sannong.

It is necessary to further point out that due to differences in their macroeconomic contexts and institutional orientation between the 1997 crisis and the three crises ending up at hard-landing in cities before that, the respective measures adopted were remarkably different. So were their impact on the sannong.

After the 5th crisis broke out in cities in 1980 many enterprises were closed down or merged, or transited to other operations. The consequence was the emergence of large numbers of unemployed youths, which gave rise to crimes and delinquency issues. To deal with the severe situation, the central government launched two major crack-down campaigns.

Yet the 5th crisis had precisely been the impetus for the rural reform, and had occurred in step with the rural reform. By making use of the sannong to develop county economy involving mainly rural industrialization and townization (an appropriate scale of urbanization in organic relation with the rural), it was possible to substantially boost domestic demand with the peasants as consumers. That in turn had kick-started the national economic recovery, and before 
long a high growth resumed. Regretfully, this self-initiated institutional experience embodying Chinese characteristics that had driven countrywide economic growth largely through domestic demands from rural sector have been interpreted through the ideology of vulgar economics, resulting in the failure to learn from this experience as a reference for analysis and comparison to deal with problems.

As for the 6th crisis in 1988, although it had still ended with a typical hard-landing in cities, under the dual structure of urban-rural dichotomy, the rural enterprises had been the first to take the impact of government macro regulation. The costs of the crisis were partially transferred to the sannong. The repercussions were wide-spread closing down of rural enterprises and an accelerating decline in non-agricultural employment as well as in peasant cash incomes for three consecutive years. What inevitably resulted was the decline of domestic demand, and that in turn led to the transformation of GDP growth driven by domestic demand to its partial reliance on external demands (export).

The 7th crisis in 1993-1994, if analysis is to be made based on its nature rather than simply as a cyclical phenomenon, it could be considered as an extension of the 1988-1989 crisis. The policy makers back then, lacking experience in handling this stagflation crisis thus adopting inappropriate measures, had created too high a cost which gave rise to the 1993-1994 crisis. If historical comparisons are made on a nonideological manner, then this crisis would be comparable to the Great Depression that swept through the West in 1929-1933.

Based on an objective analysis, the major cause of the 7 th crisis was economic overheating due to regional overinvestment across the country, stimulated by Deng's Southern Inspection speech that justified a greater autonomy to local authorities. Having to bear the full liabilities for foreign debts incurred by regional investments but taking little institutional gains from it, the central government initiated in emergency the 'monetization' reform, with its institutional gain completely belonging to the central government. That was accompanied by the bloom of three major high-risk markets-real estate, stocks and futures - with turbulent volatility. Eventually, by the end of 1993 serious deficits appeared in fiscal budget, state financial system and balance of payments along with the inflation surge. Next, the central government introduced in 1994 the 
tax division reform while expanding public debts and money supply on a large scale. Moreover, the RMB was devaluated by a staggering $52 \%$ at once. These macroeconomic reforms that aimed to secure the interests of the central government led to a surging CPI, reaching $24 \%$ in 1994 , the highest record since the Reform.

Unfortunately, these lessons with Chinese characteristics concerning government corporatism as well as the central-local governments relationship have not been seriously discussed in an objective and nonideological manner.

At that point, to alleviate fiscal pressure the government also implemented the policy of "offloading fiscal burden", or the "government retreat" as some academicians have eulogized. The SOEs underwent a wide scope of reforms. The government, which should have encouraged employment, directly pushed ahead with the policy of layoffs, streamlining and reducing headcounts to improve SOE efficiency. As a result, tens of millions of workers in SOEs who had not been in time to enjoy mandatory social security plans set up by the government were forced to leave their workplaces with little compensation. Many were forced to cash in their tenure at a low rate, becoming a group of "three no's" - no jobs, no security and no housing.

This kind of practical experience of weathering serious crisis by "deepening reform" is not something that any country in the world would dare to learn from, not to mention the European countries in the midst of a debt crisis.

Nevertheless, for the sannong, the impact of this round of governmental policies was relatively positive. In order to control the impact of inflation on the peasants, the central government was raising the official price of staple grain consecutively by more than $100 \%$ for three years from 1993 to 1996 . It in practice stabilized the peasants' agricultural income growth in that period. Furthermore, the reform in 1992 of completely abolishing the food coupons system had largely removed the main obstacle of rural to urban mobility. The tide of "migrant workers" took shape from there.

These cyclical crises occurring during the intermediate phase of industrialization are to be analyzed in more details in following pages. 


\section{1979-1980: The First Economic Crisis since the Reform and Economic Recovery with the Help of the Sannong}

Up until now, when people talk about the marketization reform of Chinese economy, they would as a rule consider the CPC Third Plenary of the 11th Congress in 1978 as the starting point. Very few people however have seriously looked into the relevant documents from that meeting which is regarded as a historical milestone. The question is: was there any reference in those documents that clearly indicated the initiation of marketization by the CPC? If one could not find such reference, then one should simply resort to a patient examination of what actually happened at that time and how the government responded to it.

We have already pointed out in previous researches that China's economic institutional reforms usually originated from responsive measures taken by the government in times of economic crisis. ${ }^{1}$ Nevertheless, people are generally bound by particular ideological inclinations and would not discuss it from that perspective.

The central government had started the dual-price system reform as early as 1979, allowing both central planning and market to set prices on targeted goods with the same value. In the same year, a decision was also made to transform the international trade system. Any projects that could help to ease the pressure of repaying foreign debts would be approved.

It is necessary to further point out that the over-investments in urban industries in late 1970s even under the pressure of foreign debts and budget deficits would inevitably lead to economic crisis and depression, and so they did come one after the other in 1979-1981. With the passing away of Mao in 1976, the government in a transition phase could no longer directly transfer the crisis costs to the sannong as it did in previous crises. Consequently the crisis had a hard-landing in cities, which then led to the rural reform, referred to as 'Household Contract' system,

\footnotetext{
${ }^{1}$ Wen Tiejun, '中国经验与比较优势 (Chinese Experience and Comparative Advantage)', 开放 时代 (Open Era), 2008(2).
} 
which in essence meant the government's retreat from the non-profitable agriculture sector.

Since certain important institutions in the rural economy previously carried by collective organizations (such as irrigation, rural credit unions, grain stations and various agriculture-related departments) had to bear the costs of the institutional transformation regarding the government's retreat, the institutional gains were also by and large left with the rural regions. Thus, almost simultaneous to the micro-economic reform of reviving peasant mixed operation on a household basis, the rural sector took the opportunity to develop autonomous industries, commerce and finance. Through this development, the rural economy rapidly stimulated China's economic recovery to another phase of high growth (Images 2 and 3).

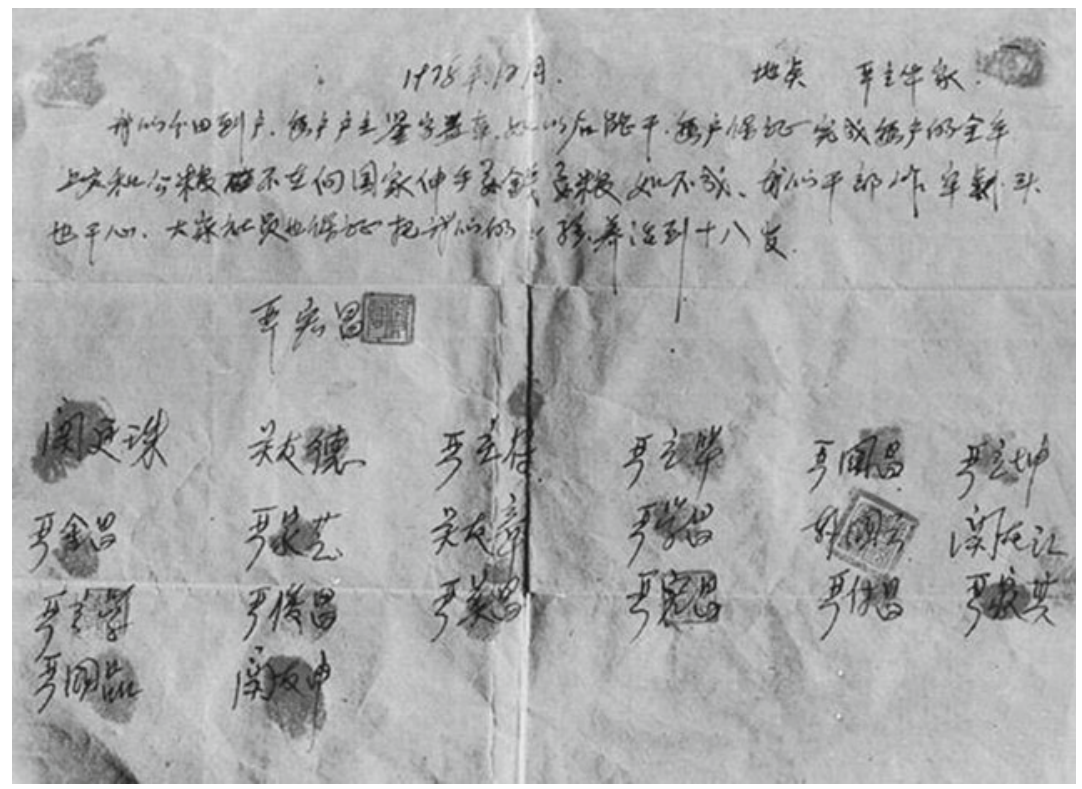

Image 2 In December 1978, 18 peasants from Xiaogang Village signed the household contract with their fingerprints in red. According to an interview with the then local party committee secretary, this contract kept in the museum is not the original, but a replicate 


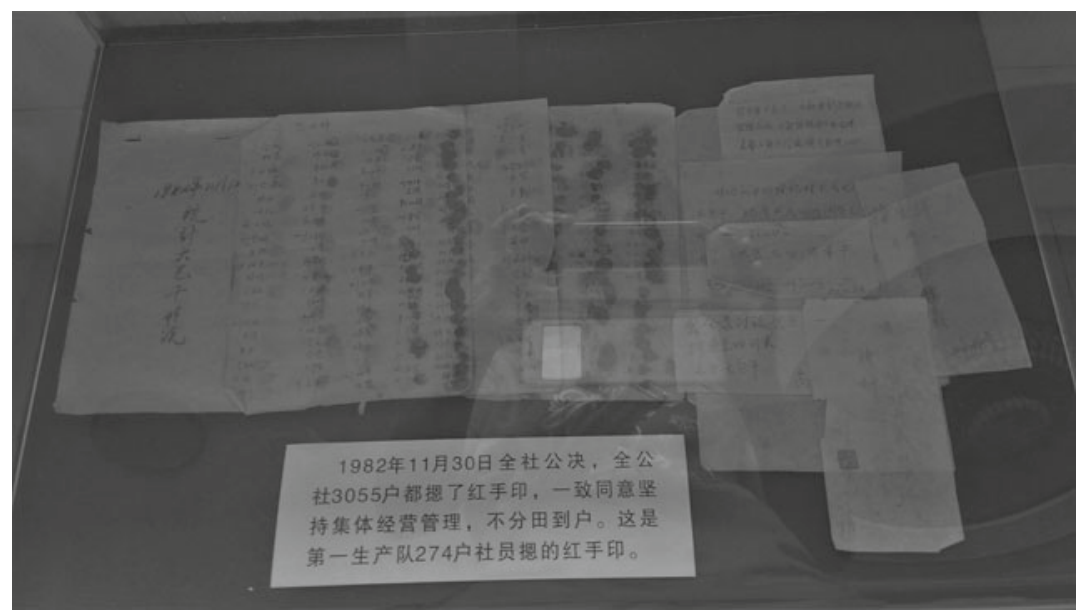

Image 3 In November 1982, members of the Zhoujiazhuang Commune signed with red fingerprints appealing to maintain the commune system (Source: Zhoujiazhuang People's Commune Exhibition Hall, Jinzhou, Hebei Province)

\section{How the First Crisis Since the Reform Happened and the Characteristics It Displayed}

If the year 1978 is to be regarded as the starting point of reform following mainstream ideology, then it was right at the first step of reform in the years 1979-1981 that an economic crisis took place.

After the surge of investments in 1978-1979, and given the strict austerity measures adopted, China tumbled into serious depression. Considering the fact that under a market economic system people would usually use the macro-economic growth rate as a measure to tell whether an economic crisis occur or not, we may look into the figures at that time. The economic growth recorded a decline from $11.7 \%$ in 1978 to $5.2 \%$ in 1981 . The growth of fixed investments, represented mainly by fixed asset investments in SOEs, showed even more severe decline, from $22 \%$ in 1978 to barely $4.58 \%$ in 1979 . It then went up to $6.65 \%$ in 1980 but a negative growth of $-10.51 \%$ was recorded in 1981 .

The economic crisis this time was mainly caused by the huge fiscal deficits that had emerged in the late 1970s. The reason was two-fold: 
first the accumulation of over investments since the 1970s and second, the recuperative policy adopted by the government in a transition phase, with the consequence of a rapid increase of welfare and subsidy expenditures. In early 1970s Zhou Enlai personally formulated and directed the " 43 " project, importing western industrial equipment and facilities valued at US\$ 4.3 billion, with the aim of making use of the technology, management and services by developed countries to adjust China's domestic industrial structure that was weighted toward military and heavy industries. From mid-1960s to the 1970s China imported mechanical equipment on a large scale through deferred payment and foreign currency deposits in the Bank of China, totaling US\$ 4.24 billion. ${ }^{2}$ That became a crucial reason of its fiscal deficits exceeding 10 billion yuan since 1974 .

The accumulated fiscal deficits from the 4th Five-year Plan, drawn up in conjunction with the "43" project, was yet to be settled. Under such circumstances the new leadership made further attempts in 19761978 to expand the scale of introducing technology from the West. The proposal budget was US\$ 8.2 billion while there was no assessment of project feasibility and domestic capability to accommodate these projects. In implementation, 22 mega project agreements were signed with foreign countries in 1978 alone, amounting to as much as US\$ 7.8 billion. In addition there was another US $\$ 5$ billion of projects from memorandums of intention that were yet to be signed. The total fiscal revenue that year in China was only 113.2 billion yuan.

The Chinese economy was then run differently from a market economy. When the Reform first started, China was still under a system in which the government centralized investments and played a dominant role in allocating resource. The government was the largest investment agent and actor. Therefore, over-investment would put an enormous pressure on the fiscal budget. Furthermore, prompted by the impetus arising from the endeavors by local governments and various authorities, over investment would often keep its momentum.

\footnotetext{
${ }^{2}$ Shi Lin (石林), 当代中国的对外经济合作 (Foreign Economic Cooperation in Contemporary China). China Social Science Press, 1989: 320. Quoted from Cui Xinjian (崔新健), 中国利 用外资三十年 (China Making Use of Foreign Capitals for Thirty Years). China Financial \& Economic Publishing House, 2008: 6.
} 
Even though the central government had put forth the slogan of "finetune, rectify, reform, enhance" in 1979 and a key policy was to cut the scale of investment, it was not actually reduced in 1979-1980.

\section{Box 1: Over-Investment in Industrialization 1978-1981}

In November 1977, the National Planning Meeting proposed that by the end of 20th century, the production volume of major industrial products would come close, catch up and then overtake most developed capitalist countries. Key industrial production would become automated. Mass transit would be on high-speed to a large extent. And key production skills would be modernized. Various economic and technological benchmarks would also close up on, catch up and surpass the advanced level of the world. In the government report presented in February 1978, Hua Guofeng proposed to undertake around 120 major projects during 1978-1985, in the areas of fuel, power, steel, non-ferrous metals, chemical industry as well as railroad, ports and so on. Among these were 30 major power stations, 8 major coal mining bases, 10 major oil and natural gas fields, 10 major iron and steel factories and 9 major non-ferrous metal factories. In July 1978, the State Council Discussion Meeting further proposed a "Great Leap Forward" to make use of foreign capitals boldly and import advanced technology and equipment on a large scale.

In 1978 alone, agreements were signed with foreign countries to introduce 22 major projects from abroad. Adding to that the memorandums of intent, a total of US\$13 billion, about RMB 39 billion would be needed. And adding the domestic matching ancillary projects of over 20 billion yuan, the total amount was more than 60 billion yuan.

Of the 22 projects to be imported in whole, about half in terms of the total transactional value were actually signed hurriedly during the last ten days of 1978, many of them previously not included in the original plan.

In terms of the actual implementation, the total investment on SOE fixed asset countrywide in 1978 was 66.9 billion yuan, an increase of $21.9 \%$ from the year before. Among this, infrastructure building totaled 50.1 billion yuan, higher than the previous year by $31.1 \%$. Industrial infrastructure amounted to 27.3 billion yuan, an increase of $55.8 \%$. At 
the end of 1978, projects-in-progress in enterprise under the Whole People Ownership numbered 65,000 with a total investment of 370 billion yuan. 8.3 million tons of steel was imported in 1978, higher than 1977 by $65 \%$. The imported quantity had accounted for $37.6 \%$ of total domestic production but it was still insufficient to meet the demand.

Since the proportion of heavy to light industries was out of balance, the differential between the supply of market goods and the purchasing power was as high as 10 billion yuan.

Beginning in 1979, China undertook adjustments of the national economy. The State Planning Commission made major amendment to the original plan. The growth rate of total industrial production had been tuned to $8 \%$ from the original $10-12 \%$. In actual, total industrial production value in 1979 reached 468 billion yuan, higher than the prior year by $8.8 \%$. It grew to 515.4 billion yuan in 1980 , an annual growth of 9.3\%. To cool down the overheating, 295 large and medium size projects were aborted or decelerated in 1979. Another 283 projects were further cut in 1980.

The regulation in 1979-1980 had been effective. Nevertheless it did not resolve one important problem that it should have, i.e. to suppress the scale of infrastructure investments. Infrastructure investments that were included in the 1979 state budget, after adjustment, was 36 billion yuan, lower than the previous year by 3.6 billion yuan. However, the actual number came to 39.5 billion yuan, only 0.1 billion yuan lower than 1978. For 1980, the budget was 24.1 billion yuan while in actual 28.1 billion. It did appear lower from the previous year by $28.9 \%$. Yet, outside of the budget, various local authorities, sectors and enterprises had year over year increased in self-financed investments of $56.2 \%$. As such, the total investments in 1980 actually came to 53.9 billion, higher than 1979 by $7.8 \%$ and the highest record in 30 years since 1949-1980. Among these, investments on industrial infrastructure (including those outside the budget) remained high as 29.2 billion, at par with the 1978 level and more than 1979 by 1.03 billion.

Source: Wang Haibo (汪海波) 中華人民共和國工業絕濟史 (History of Industrial Economy in PRC). Shanxi Economic Publishing House: 1998, pp. 498-500, 506-507, 510-511. 
In a country where the primitive accumulation happened endogenously, high level of investments during industrialization would mean a high degree of concentration and accumulation of social wealth. Yet looking at the actual situation, the accumulation rate in China had declined substantially in the period 1979-1982. A fast growth in various subsidies and welfare expenditures was one of the causes of fiscal difficulty. The policy makers back then had a consensus about this. The backdrop was that the industrial primitive accumulation from the 1950s to 1978 had relied mainly on excessive extraction of surplus from the society. As a result all the labor workers in the society-urban and rural-had been living at subsistence level during that period. Before the Third Plenary of the CPC 11th Congress in December 1978, the new administration put forward a new policy directive to build a moderately well-off society, with a series of recuperative measures: in cities, increasing the subsidies to SOEs to award bonuses to workers, improving workers housing condition, promoting employment and so on; in rural areas, raising the prices of agricultural produce, exempting taxes in poor regions, increasing agricultural support and so on. Given the political background at that time, these policies also had the political consideration of maintaining social stability during the transition from the first generation leadership to the second, i.e. by lowering the primitive accumulation in the society to exchange for majority support. In May 1978, the State Council made the decision that enterprises which had gone through a clean-up process and were in good operating conditions could experiment on bonus system and limited piecework wage. The proportion of bonus would in general not exceed $10 \%$ of an enterprise standard salary. $^{3}$

3 中華人民共和國工羓緢湾史 (History of Industrial Economy in PRC: October 1949 to 1998), p. 497. 


\section{Box 2: Government Work Report Regarding Subsidies and Welfare Expenditures}

Based on the 1980 Report on the Work of the Government, peasants' income in 1979 had increased by 10.8 billion yuan thanks to the development of agricultural production and a higher purchase prices of produce. Furthermore, with the exemption and reduction of taxes on agriculture and rural enterprises, peasants' tax burden was cut by 2 billion yuan. The income that was allocated to the peasants by the collectives had reached 83.4 yuan per person, higher than 1978 by 9.4 yuan, compared with an increase of 10.5 yuan only during the entire 11year period from 1965 to 1976 . In 1979, over 9 million people were given employment in cities. $40 \%$ of workers had salary rank promotion. Wage categories were adjusted in some regions. Subsidies for non-staple food were given to employees and bonus system was generally adopted in enterprises. The total salary paid to enterprise employees under the Whole People Ownership, including bonuses, had increased by 6 billion yuan from the prior year. Annual salary on average reached 705 yuan, higher than the year before by 61 yuan. New housing accommodation for the workers built in 1979 totaled 62.5 million square meters, higher than the previous year by $66 \%$ and highest since 1949 . In the first half of 1980, the total accommodation space built came to 73.7 million sq. m. (Source: Report on the Work of the Government 1980 delivered by Vice Premier Yao Yilin on 30 August, 1980 at the Third Session of the Fifth National People's Congress: 'Report on 1980-1981 National Economic Plan Implementation'.)

Based on the 1981 Government Report, with higher purchasing prices for agricultural products paid by the state and the tax exemption on certain rural regions, the fiscal revenues recorded a total decrease of 52 billion yuan in 1979-1981. Moreover, with employments provided to over 20 million people, rural and urban combined, as well as rises in salary and adoption of bonus schemes, the total impact on the fiscal budget was 40.5 billion yuan. These two items totaling 92.5 billion exceeded the budget by more than $54 \%$. Furthermore, state subsidies on agriculture-related use of fuel, electricity and fertilizers as well as on import of grain, cotton, sugar etc. amounted to 23.4 billion yuan. The weight of consumption in national income increased from $63.5 \%$ in 
1978 to around $70 \%$ in 1981 while the proportion of capital accumulation went down correspondingly from $36.5 \%$ to 30\%. (Source: Report on the Work of the Government 1981 delivered by then Premier Zhao Ziyang on 30 November and 1 December 1981 at the Fourth Session of the Fifth National People's Congress: 'Current Economic Situation and Direction of Economic Construction in Future'.)

The 1982 Report presented more details: from 1979 to 1981, 44.2 billion yuan was spent on raising the purchase prices of produce, 30 billion yuan on raising salary and bonus scheme, 10.5 billion yuan on providing employment for 26 million people in cities and towns, 15.2 billion yuan on increasing worker housing. In addition, rural tax exemption, increased subsidy on imported commodities and so on added up to a total expenditure of more than 140 billion yuan. (Source: Report on the Work of the Government 1982 by then Premier Zhao Ziyang on 30 November 1982 at the Fifth Session of the Fifth National People's Congress: 'Report on the Sixth Five-Year Plan'.)

The 1983 report summarized the living standard improvement for the people during the five years 1978-1982: average net income per capita for peasants reached 270 yuan in 1982, doubling that of 1978. During the five years, newly built accommodation in rural regions totaled 2.2 billion sq. m., with tens of millions of peasants moving into new homes. In cities and towns, employment was arranged for more than 38 million people. Furthermore, with wage increases and bonus scheme, the livelihood of workers also saw notable improvements. In 1982, workers in cities on average had disposable income of 500 yuan. Discounting the inflation factor, the growth was $38.3 \%$ from 1978. During the five years, state expenditures on urban worker accommodations came to 448 billion yuan with an area of 350 million sq. m., equaling the total area built in the 19 years before 1977 .

Source: Report on the Work of the Government 1983 by then Premier Zhao Ziyang on 6 June 1983 at the First Session of the Sixth National People's Congress.

Considering the above two aspects in combination, the cause of the 1979-1981 fiscal crisis could be summarized as follows. With limited fiscal revenues, the government nevertheless wanted on one hand to strengthen industrial infrastructures by higher investment, and on the 
other hand prioritize the improvement on people's living standard. Both were beneficial to consolidating the new administration's legitimacy. Yet the generous outlays spent simultaneously on these two fronts were in competition with each other for the limited fiscal revenues. A society that had no resources coming from outside could hardly have high accumulation as well as high consumption at the same time. Whatever political system it adopts, relying on fiscal deficits and over-drawing government credit, a government would eventually result in severe fiscal difficulties.

In reality, the contradiction between consumption and accumulation had been concomitant with the primitive accumulation for industrialization in the first 30 years of the socialist China. Coming to 1979-1981 at the early days after the passing away of the first generation core leadership and with the coming on stage of the second generation, the choices the latter made were implicitly in line with the changes in the political situation at that particular moment. On the surface, welfare expenditures were non-elastic. A deeper reason was the rendering of social resources into social capital required particular historical condition and social background.

Quoting from the Report on the Work of the Government 1981, "[s]ince 1979, various expenditures for improving people's livelihood have increased substantially. Although the pace might be somewhat fast, yet overall it has been done right. At the same time, the reduction on infrastructure investments that was planned in the budget was not sufficiently met, and administration expenses have also continued to rise. That has resulted in total expenditures exceeding total fiscal revenues. Very large fiscal deficits have appeared in 1979 and 1980 consecutively. Money supply has been too high and general price is rising." Based on this report, the budget deficits in 1979 and 1980 were 17 and 12.7 billon yuan respectively. ${ }^{4}$

Yet in subsequent policy documents, the "over investment" took the "main responsibility" for the fiscal crisis and economic crisis.

In fact, whether the new administration had focused on investment or consumption, the transition of power that was completed in late 1970s to early 1980s ultimately had to pay the price in the form of an economic

\footnotetext{
${ }^{4}$ Quoted from History of Industrial Economy in PRC October 1949 to 1998, p. 497.
} 
crisis. Furthermore, there was a causal relationship between that crisis and the economic reform.

Box 3: Contents in the Report on the Work of the Government Relevant to the Recognition of Fiscal Deficits as a Cause of the Crisis and Its Measures

With regard to the possible repercussions of large fiscal deficits, the central government was obviously well-aware. "If effective measures are not taken to resolve the problem, there will be another deficit of 11 billion yuan in 1981. In that case, the improvements that people had in the past few years would be lost. The situation of imbalance would further deteriorate. Serious disorder would occur in the national economy. The stable and cohesive political situation could hardly be consolidated and developed. (Source: Report on the Work of the Government presented at the Fourth Session of the Fifth National People's Congress: 'Current Economic Situation and Direction of Economic Construction in Future').

The government had made pertinacious effort since the winter of 1980 to cut the budget deficit. The deficit was cut to 2.5 billion yuan in 1981, a decrease of more than 10 billion. The fiscal expenditure in 1981 was lower than the 1979 level by around 25 billion yuan. Most of this was realized by suppressing infrastructure projects in state-owned units and sectors.

Sources: Reports on the Work of the Government 1981, 1982, 1983.

Economic crises had always been accompanied by high unemployment, not to mention a large number of youths returning from countryside to cities since 1978 that drastically added to the employment pressure in cities. From 31 October to 10 December 1978, the second "National Working Meeting on Intellectual Youths Going to Mountains and Villages" was convened in Beijing. Two important documents came out: the meeting minutes and the State Council document on temporary measures regarding the matter. The key point was that while the "going to mountains and to village" should persevere yet the conditions for another mobilization were not suitable. Its scope was to be gradually reduced. Cities that could accommodate the youths with employment 
needed not engage in such mobilization. Towns and cities should actively explore new realms and create new occupation and employment opportunity. This meeting and its documents signaled the historical turning point on intellectual youths' deployment to mountains and villages in China. There were still 1.7 million of them in 1977. By 1978 the number sharply dropped to 480 thousand and further went down to 247.7 thousand in 1979, most of them staying in suburb farms and factories. Entering mid 1980s, there was no more mobilization in most regions.

A large number of youths returning to cities instantly turned into an employment problem. Adding to the growing labor force and those still seeking employment, the total number of urban citizens waiting to be employed reached a peak of 15 million. That was just the official statistics. Different sources indicated that the unemployed population in cities during 1980-1982 was much higher. Some estimated that it might be as high as 40 million. Still, compared to 1960-1962 when the employment in cities and towns was cut down by 80 million, the situation was not as severe. However, given that it was not possible to transfer the surplus labor to villages as before, a large number of unemployed urban population in cities directly led to a deterioration of social order. The crime and delinquency rate was almost as high as in 1950 right after the establishment of the new regime.

In response to the delinquency problem in cities, a conference was convened in the winter of 1979 , followed by a meeting by the CPC Central Political and Legal Affairs Commission in Beijing focusing on the situations in five major cities. Two strong Crack-down Campaigns were then launched.

\section{The 1980 Economic Crisis Hard-Landing in Cities; Revival with the Help of the Sannong}

Given that this economic crisis had arisen due to the fiscal deficit crisis in late 1970s, anything that could help alleviate the fiscal pressure would be accepted by the state for policy consideration. 
It could be seen that while the crisis had a hard-landing in cities it was the sannong that helped to stimulate the revival and growth of the economy.

\section{Reforms on Two Aspects in Rural Policy}

a. Comprehensive reform of basic rural operating system:

The Household Contract System was launched whereby the production-operation entitlements of agrarian land was allocated to rural households based on headcount. At the same time government's financial support of agriculture was largely cut. In effect the government had retreated from the non-profitable collectivized agriculture in order to alleviate part of its fiscal deficit pressure.

To revive the economy and improve employment, the central government officials in-charge of planning had proposed "offloading some fiscal burdens both in industrial and agricultural sectors," "in [poorer] provinces like Gansu, Inner Mongolia, Guizhou and Yunnan. The central government had to allocate to them a large quantity of staple grain; they are heavy burdens to the state". "[Is it possible to consider] adopting Household Contract or some such schemes in sparsely populated regions with backward and poor economic condition? Let them find ways to look after themselves and reduce the burden on the state." According to Mr. Du Runsang, he had proposed to the then Vice Premier and Director of State Planning Commission Yao Yilin "adopting household contract system in poor regions. Let the peasants contract on production, which would be beneficial to both sides." When Yao reported to Deng Xiaoping, he had mentioned offloading burdens in industrial and agricultural sectors. ${ }^{5}$ The rural reform that was launched in full-blown fashion on 1 January 1982 coincided with the urban economic crisis. It could be seen that the rural household contract system was beneficial to the government quickly emerging out of the fiscal crisis.

\footnotetext{
${ }^{5} \mathrm{Du}$ Runsang (杜润生), 杜润生自述: 中国农村体制变革重大决策纪实 (Du Runsang's Narrative: Documentary on Major Decisions regarding Rural Reform in China). People's Publishing House, 2005:114-115.
} 
Agriculture was by nature not as profitable as urban industries. The reason why agricultural production in China had been even more unprofitable could be attributed to the impact of external factors. From 1972 onwards China gradually resumed diplomatic relationship with Western countries as well as Japan, and began to launch new projects involving the import of industrial equipment from these countries for light industries, petrochemical industries and those supportive to agriculture. The production of industrial goods such as chemical fertilizers and farming machineries grew up and the products were sold to rural regions through the "unified sale system". As a result, agricultural production costs went up significantly yet the "unified purchase" prices of produce remained unchanged. Therefore, even though staple grain production increased, People's Communes operated at low-efficiency and under high indebtedness. By the end of the 1970s, rural communes with heavy financial losses due to years of surplus extraction, had become "burdens" to the state budget.

In any case, the rural reform with the household contract system should be categorized in theory as a 'government retreat'. Alternatively it could be regarded as a 'deal' in which the government conceded to rural collectives and the peasants the ownership of land and other agricultural means of production, in order to shrug off its responsibilities of welfare and public management in the rural regions, and ultimately became an institutional "transaction".

In the five consecutive "Documents No. 1" since 1982 that the central government issued once a year, people would see many instances of "approval" and "allowing", an indication that the government had expressed unprecedented concessions to the peasants.

Yet due to conservative, institutional and ideological constraints, it had not been possible for the new scene to sweep the country in one go. Certain provinces and regions (for example Heilongjiang Province and Yantai in Shandong) where there were relatively sizeable farming areas with mechanized cultivation even refused to adopt the Household Contract system. Therefore the central government pushed forward the new system in 1984 with a political approach. Since then, the rural ownership was completely transformed, with the result that the 
actors of rural interest changed from the previous 700 thousand production brigades and 4.8 million production teams to 200 million peasant households.

On one hand, the implementation of Household Contract system fundamentally dismantled the collectivization system established in early 1960 s to serve urban industrial primitive accumulation. The model of "three-tier ownership with brigade as the basic unit" in scale agricultural operation was changed to a two-tier mechanism, in which scattered peasant households with their multi-occupational operations became the main agents, while rural collectives were retained to perform certain service and management functions. The rural collective ownership generally had production teams (natural village) as the basic unit. Certain regions had brigades (administrative village) as the basic unit. And in isolated cases the commune (township) was kept as the unit. As such, while acknowledging the communal collectives having the fundamental land ownership, accompanied by the right of land adjustment and rent collection (as a sort of contract fee), the peasants themselves were entitled with the household contract right - the autonomy of production and the right to operational profits.

On the other hand, since 1979 the government had raised the purchase price of staple grain as part of the rural "recuperation" policy. The price increases of six major kinds of grain were as much as $20.8 \%$ in 1979. Since then, the unified purchase price had been further raised while the unified purchase volume was lowered accordingly. With the dual price mechanism, state controls were gradually reduced over the pricing and distribution of produce, as well as over the prices of key production factors. The scope for adjustments by the market was expanded. The price surge on agricultural products as a result of these marketization-oriented policy adjustments had reached 49\%. The peasants had more profits and therefore pursued higher production. It was breaking through the welfare-type allocation based on headcounts back in the period of collectivization, necessitated by the high level of agricultural surplus being extracted by the state, with little remaining for the collectives to allocate. It was a realization of the "higher pay for more work" type allocation, not possible in the past while the state appropriated the larger part of the surplus at a low or even no cost. 
The previous ten years of collectivization did have the positive effect of large-scale input of labor into infrastructure building such as irrigation system. That was also one fundamental reason why agricultural production could substantially increase after the reform. The common explanation back then of the exceptionally high agricultural production increment was that each of the above three factors-household contract system, price adjustment and infrastructure building-had contributed one-third towards the result.

b. "Self-capitalization of Rural Resources" in the form of rural industrialization and townization

The government had, since the start of People's Commune system in 1958, encouraged rural collectives to develop five mini-industries locally. Later, with the onset of a vicious economic crisis in 1960, rural industries had been restrained. In the late 1970s, the government again allowed the peasants to employ workers or to become self-employed in industries and commerce previously monopolized by the state. At that time it already initiated a sannong development path with Chinese characteristics, which promoted peasants' non-agricultural employment and incomes through rural autonomous industrialization and townization. ${ }^{6}$ The policy that encouraged rural industrialization, simultaneous with the household contract system, suited the institutional needs of micro primitive accumulation of capital for the numerous and widelyscattered rural industrial and commercial enterprises. On one hand the rural reform of early 1980s nurtured the development of rural enterprises and townization in rural regions, which in turn became the effective factors stimulating domestic demands that drove economic growth. On the other hand, however, because of the large quantity of resources and industrial goods taken up in the process, the inflation that emerged in 1988 , exacerbated by the attempt of price reform, cumulated in the next economic crisis - the sixth in the 60 years of industrialization in China, or the second since the Reform and Opening Up.

\footnotetext{
${ }^{6}$ According to the 2008 China Statistical Yearbook, the number of workers in rural enterprises was 30 million in 1980, 70 million in 1985 and 150 million in 2007.
} 
During the 1979-1984 rural reform, the government retreated from the realms where it previously had fiscal responsibilities. In addition to giving the peasants the right to profits from agricultural surplus, the government also returned to the peasants the right to "capitalize" key local production factors (rural land, labor and so on) and to profit from it. Since then, rural industries operated at the brigade level were viewed as the important means of subsidizing the agricultural sector, hence given policy favors to some extent. On 3 July 1979 the State Council promulgated the "Trial Draft on Regulations Regarding Certain Issues Relating to the Development of Brigade Enterprises" which explained the significance of brigade enterprises: "the development of brigade enterprise would first of all serve to improve agricultural production, strengthen the collective economy at both the commune and the brigade levels and finance the necessary funds for agricultural mechanization; and secondly open up production opportunities for the labor force that became surplus by agricultural mechanization, thereby fully utilizing local resources to develop diversified operations, increase income for the collectives and raise members' living standard." It also pointed out that "the development of commune enterprises on a large scale could provide a large supply of raw materials and industrial products to the society, expediting national industrialization, while at the same time avoid the pitfall of over concentration of industrialization in mega and medium cities, an important means for narrowing over time the gaps between industry and agriculture as well as the urban and the rural". There were clear regulations on the deployment of brigade enterprise profits, "other than investing in the expansion, reproduction and setting up of new enterprises, it should be used in agricultural infrastructure building, mechanization and supporting brigades in poverty." Since the 1980s, the utilization was further transformed, with part of the profits directly allocated to members in accordance with headcounts or acreage to subsidize their incomes. After the Joint Production Responsibilities Contract system, the productions of staple grain and cottons were subsidized to fulfill the state's purchase target. In some cases, subsidies were given to supplementary operations such as raising livestock, aiming to stimulate the peasants' incentive. Thus, rural enterprise became the main agents for the capitalization of rural land and labor resources. 
With rural industries and commerce rapidly taking up land, labor and other rural resources, a large number of peasants left agriculture to rural enterprises or went to towns. The rural economy therefore realized a comprehensive development relying on autonomous industrialization and townization.

Yet there were unfavorable institutional factors-whenever a government, under any political system, had to respond to an inflation-type economic crisis, it would adopt austerity measures that hurt small and medium businesses first and foremost. Faced with the 1979-1981 economic crisis, brigade enterprises still at the primitive accumulation phase bore the brunt of being constrained. Some major industries in cities went into a quagmire due to lack of raw materials, and appealed to the government to adjust the policy orientation. As a result, there were debates around whether brigade enterprises were crowding out the bigger and more advanced urban enterprises.

Relevant research showed that this situation was not really caused by the growth of brigade enterprises. Surveys organized by the State Machinery Commission found that "brigade mechanical industrial products had both crowding out and ancillary effects on large state-owned factories. At this time the ancillary effect is larger than the crowding out." Afterwards, the report was submitted to the CPC Central Committee and the State Council and terminated the debate. ${ }^{7}$ Yet the document "Certain regulations by the State Council to adjust Policies regarding Brigade Enterprises" that came out in May 1981 still regarded brigade enterprises as having crowding out the raw materials that should have gone to large urban enterprises. On that basis rural enterprises were to be regulated. It further re-emphasized that brigade enterprises would only be allowed to operate on the premise that they did not impact major urban industries, which meant mainly the processing of local produce. Under permissible conditions they might also engage in the supply of parts and components to facilitate the development of urban industries.

Following that, other policies were also put forth, such as higher taxation targeting brigade enterprises, tightening credits to them, and so on. Nevertheless, given that the primitive capital accumulation for

${ }^{7}$ See: Chinese Rural Enterprise Yearbook (1978-1987), China Agriculture Press, 1989. 
rural industries and commerce had relied mainly on the mechanism of internalization in rural communities or households, i.e. large scale and intensive input of labor regardless of costs, a form of self-exploitation, unlike state-owned industrial sectors that relied on state revenues and debts for support. Furthermore, given that the consumer goods market in China in mid-1980s was in general supply shortage, rural enterprises still had sufficient room to develop. The comprehensive development of rural economy not only led to rapid income growth among peasants but also spurred a rapid revival of the national economy.

To summarize, in the economic crisis that broke out in 1981, on one side the government no longer had the conditions to mobilize surplus urban labors "going to mountains and villages" as in the 1960s-1970s. Not only that, they had to accommodate the tens of millions of youths returning from villages. That meant the crisis could only have a hardlanding in cities. On the other side, the rural policies, with historical particularities, were practical to the situation, releasing rural productivity and generating a positive institutional reform for the rural economy. As a result, rural economic growth accelerated after 1982, especially for rural enterprises. Not only were the latter not constrained by the unfavorable policies advocated by the vested-interests in urban sector, they even formed a strong new force by 1984 that stimulated the recovery and the subsequent growth of Chinese economy overall.

\section{Three Factors by Which Rural Industrialization Facilitated the Recovery of National Economy}

The acceleration of rural industrialization may be attributed to the three following factors with typical Chinese characteristics.

The first factor was the peasantry. Rural population accounted for $80 \%$ of the total population in the 1980 s. Given that peasantry incentive was the first essential factor of productivity, with the release of their initiative over a short span, an opportunity return thus emerged. The "recuperation" policies in early 1980s had enabled the peasants to retain their labor force used to be appropriated and the agricultural surplus that was extracted by the government at no cost. Furthermore, the peasants 
attained higher cash income level with the policy of raising the unified purchase price of produce to promote productivity. With regard to the national economy, the peasants with their higher cash income hence higher purchasing power filled the gaps in demand that had been affected by the over-tightening of urban industries. Besides, with the anticipation of sharing in the opportunity return of rural industrialization and townization, the peasants had the initiation to increase investment, boosting the demand on industrial goods. In turn they provided large quantities of low-quality yet low-cost consumer goods to the society, leading to higher turnover of tangible goods on the market and thereby absorbing the possible risks of inflation due to higher fiscal deficits and money supply expansion by the government.

The second factor was the rural communities. In the $1980 \mathrm{~s}$ there were 780,000 brigade-level administrative villages and 3.8 million teamlevel natural villages around the country that still practiced common collective ownership. Around two-third of the rural communities still had collective assets and revenues to be distributed to members. Therefore, the traditional rural communal rationality mechanism was able to function in the process of rural industrialization-rural collectives, making use of the newly-released production factors (collective funds, highly-disciplined labor force and land resources), took on the primitive accumulation for industrialization at a low cost, and dealt with the risk of externality by internalizing it.

The third factor was the market. The Reform's market-orientation and the initial opening up of the market for consumer goods resulted in a rocketing demand of general low-quality consumables. At that period urban state industry was still mainly comprised of military and heavy industries, yet to be transformed to satisfy the demand on general consumables. However, rural industrialization was by nature oriented towards consumable goods production and therefore able to fill the huge low-price consumable market with almost no competition.

It could be seen from statistical data that brigade industries, even while disadvantaged by macro-economic regulation oriented to the interests of urban industries, still displayed an institutional advantage of that selfinitiated rural development with Chinese characteristics. From the start 
of rural industrialization to the year 1988, the production of rural enterprises had an average annual growth of over $30 \%$, higher than that of state-run industries in the same period by more than $10 \%$ points, and also higher than the total production volume by a similar margin. With its primitive capital accumulation being completed internally over a short span of time, it became a main force capable of supporting the rural as well as the entire national economy.

\section{Experience and Lessons from Handling of the 1979-1981 Crisis}

In response to this crisis that happened in the early days of the Reform, the government, having great difficulties in applying macro-regulation, decided to retreat from the collectivized agriculture that was recording heavy losses. On one side, the Household Contract system had returned to the peasants almost all land and labor force. On the other side, the controls over rural markets and essential production factors were relaxed in order to stimulate the peasants' initiative to develop production. Such was the essential substance of the five successive Central Documents Number One issued annually in the 1980s.

What followed after 1983 was a period of high growth for five to six years. The development of rural small and medium enterprises had brought about rural townization and raised peasants' income level at a rapid pace for four successive years, until 1988 when inflation recurred. During that period the gap between urban and rural income narrowed at a fast pace; rural consumption grew by a large extent, at one point accounting for over $60 \%$ of total retail value. China therefore had a period of 'golden growth' in the 1980s that was driven by domestic consumption. This experience of golden growth should have been an important content of the "Scientific Outlook on Development" latterly proposed by the central government in 2003. Unfortunately it had been largely neglected by mainstream opinion during the 1990s under deliberate suppression by interest blocs at the time.

The government had attempted to suppress brigade industries to help the urban sector in the quagmire of insufficient investments during the 
economic crisis. As a rule small and medium rural enterprises bore the brunt of impact first and foremost under the austerity policies. For two reasons it was no longer possible to transfer the bulk of the costs from the urban sector to the sannong: first the disintegration of People's Communes making it impossible to repeat the campaigns of "going up to mountains and villages" as a way of directly transferring urban surplus labor, hence the costs of the crisis to the sannong. Second, the government rural policy research departments at that time could still play a role in the decision-making process, protecting the interests of the sannong. Therefore, the policies that aimed at transferring the costs to the sannong had not made real impact. ${ }^{8}$

From the above, it can be seen that China had a decade of reasonable development in the 1980s. It provided an important historical experience for the central government to adjust its strategic orientation in the twenty-first century-strengthening input into the sannong to foster its self-initiated development would build a solid base with Chinese characteristics that could help alleviate the impact of economic crises.

\section{The Profound Impact of the Institutional Costs Brought About by the Reform}

It is generally agreed that China's Reform and Opening Up in the 1980s was different from the Soviet Union's "shock therapy". The former was gradual while the latter was radical. Justin Lin Yifu et el (1984) summarized the characteristics of China's reform as "making the cake bigger", "incremental reform", "experiments then generalization" and "non-radical", and provided corresponding theoretical explanations. The view that the reform in the first half of the 1980s was of the incremental adjustment type is worthy of further discussions. Looking at the actual process, whether it was the adjustment in the fundamental land ownership, or the adjustment of the national income distribution

\footnotetext{
${ }^{8} \mathrm{~A}$ series of policies favorable to the sannong in the above-mentioned Documents were suggested by two departments, the Rural Policy Research Office of the CPC Central Committee and the State Council Rural Development Research Center. However, they were dismissed in 1989 and 1990 respectively.
} 
structure, it was in essence a structural sea change in the distribution of the assets stock. The reform at that time was essentially of the stock-adjustment type, undertaken under the pressure of crisis. If any increment was generated, it would only be the result of rural industries with much higher marginal return as compared to urban sectors. When the rural sector was given a chance of investment and funds support, the marginal returns thus generated were no doubt higher than urban industries backed up by fiscal expenditures.

Nevertheless, the theoretical interpretation of the Reform did have practical value in politics. Chinese politicians, under the pressure of further opening up to introduce foreign capital and forced into the urgent need to have dialogues with the West, accepted the discourses of the Reform, and the latter then became the mainstream. Furthermore, with China's continuous high-speed economic growth, Chinese economists who were trained by the Western system continued to sum up the experience in accordance with that discourse, and that was in turn absorbed into the analyses of Western scholars over time. In the early twenty-first century, the international media and academic mainstream's concern and assessment of China's Reform and future development gradually shifted from "China's collapse" to "China's experience" (yet it tended to be more about "China's threat"). As an attempt, see Ramo (2004), the American China expert summed up the three aspects of the development path that China went through since the Reform: "innovation and experimentation", "defense of national borders and interests" and "increasingly thoughtful accumulation of tools". In keeping with the Western convention, he coined the phrase "Beijing Consensus". During the Sub-prime Crisis that started in the U.S. in 2008 and subsequently spread to the world in the form of the financial meltdown, China's ability to maintain growth once again called the attention of the international mainstream. At that point, the concept of the "China Model", interpreted and accepted within the academia long before, became an object for sensationalism in Western society.

These studies on China's Reform and development by domestic and overseas mainstream intellectuals and media, whether they are sorting through the experiences or theorizing the process, are not irrelevant for us today to rethink the path that has been taken since the Reform and 
to maintain the mobilization mechanism endogenous in ideologies. However, today when we look into those events at the early and middle period of the Reform, it is quite difficult to have the same clear thinking that was embodied in the experience studies or theoretical evaluation described above. Much of what we find today is ideologically entrenched interpretation and ambiguous conclusions drawn by theorists taking benefits from varied interest groups. That is not to negate the effort of domestic and overseas researchers on the study of 'Chinese experience' or 'China model'. In fact not everyone would agree with the so-called 'Chinese experience' or 'China model'. Otherwise it would be hard to explain why such discourse would surface only at times of apparent success, whereas during the moments of crises in the reform the key-words were usually "collapse," "failures" and so on.

Looking at it objectively, indeed those many policies formulated and launched by the central government during the Reform and the subsequent fast growth could hardly be "a priori" innovative. Choices and decisions could only be made as a response to the situation in conformity with people's basic understanding. The targets of regulation were mostly pragmatic, unlike the conclusion deduced today from studying that experience, which is with clear foresight or scientific definitiveness and orderliness. On the contrary, back then if any point of view in relation to the superstructure or ideologies would interfere with the introduction of particular regulation, it would generally be put aside in accordance with the instruction of "no debates" and allowed to remain vague. With regard to the export-oriented economy that was strongly promoted in line with the "coastal economic development strategy", theoretical and academic discussions today are somehow superficial and often off-the-mark due to the complicated context in which such macroeconomic policies were deliberated.

Actually, as long as people are willing to go back to the economic and political situation around the time of 1978, even in a simplistic manner, it would not be difficult to attribute that round of opening to China's macro-economic conditions and institutions at that time.

During the fiscal crises in Mao's era, the mobilization of youths to "mountains and villages" by the central government to transfer the costs of crisis to rural regions was relatively effective to achieve "soft-landing" 
for the industrial capital concentrated in cities (most governments would find it hard to transfer the costs of crises to society). These three rounds of transfers in this era did incur an enormous price to be paid by both the peasants and urban residents.

Yet in the late 1970s after the death of Mao, when the new government had to deal with fiscal crisis, those in power could no longer undertake the same approach, not having the charisma of Mao. Therefore, they were obliged to adopt the approach to deal with the problems, which later were dubbed as the reform, including three famous major reforms in the 1980s_fiscal responsibility was decentralized to different administrative tiers; the funds provided to state-owned enterprises were no longer budget allocation but became loans; the enterprises did not turn over all the profits but pay tax to the government-and other institutional changes such as the factory contract system and bonus system in enterprise reforms that were replicas of the rural household contract system.

And with regard to the foreign trading system, it was also impossible not to make ground-breaking reform unprecedented in the prior thirty years. In face of the climbing fiscal deficits and a serious shortage of funds for major national industrial structure transformation that had already begun, Li Xiannian, in September 1978 in the State Council Discussion Meeting, proposed to engage in more supplementary trades so as to reduce the burden of domestic investment in relevant projects. Moreover, Deng Xiaoping's speech on "Raising the banner of Mao Zedong's thoughts, persevere in the principles of practicality and being realistic" broke through two traditional forbidden zones relating to foreign capital - foreign loans and joint ventures. In December that year, the Foreign Trade Minister announced that China would accept loans from foreign governments and allow foreign companies to make investments in China. In effect, any commonly employed practices in international trade would be permitted.

Yet such a large extent of opening to the outside of course had its institutional costs-breaking through these two forbidden zones meant that national debts would substantially increase and eventually be taken up by central government's budget. At that time, the fiscal system was unified but there were no clarification on sharing liability, power and 
benefits among various tiers of government, departments and persons in charge in regard of the large scale debt increment. This issue which has not been thoroughly discussed back then still plagues China today.

Due to lack of clarification on how to share liability, power and benefits between the central and local governments, an essential institutional problem was created wherein "the central government takes up the liability while the local takes the benefits". On that basis it inevitably led to the frenzy in coastal regions competing to open up and requesting the concession of power to set up special development zones.

The foregoing was the essential context behind the central's approval to open four special economic zones (Shenzhen, Zhuhai, Shantou and Xiamen), as well as the subsequent opening up of fourteen coastal cities.

In these two breakthroughs, the institutional costs thus incurred due to lack of clear delineation on liability, power and benefits, given with the centralized fiscal system, had no other way of being transferred but within the system itself. Impossible to transfer the cost to the sannong, a hard-landing within the urban system became inevitable, and that in turn led to an endogenous reform.

With the above elaboration, we agree with the prevalent statement that "Opening up came before the Reform and Opening up has in turn driven the Reform".

\section{The 6th Crisis (1988-1990): The Second Economic Crisis since the Reform and the Response of the Sannong}

In 1988 China experienced hyperinflation with annual CPI reaching $18.6 \%$ (the highest monthly rate after the introduction of "price reform" had been $26.7 \%$ ). What happened next was a production stagnation in 1989, with the "chain debts" among enterprises as a symptom. The combination of these two was a typical stagflation crisis. Following that was a depression in 1990. During the same period, the economic relationship had become increasingly tensed during the time of high growth. Social contradictions accumulated and eventually exploded under the 
pressure of crisis, resulting in the 1989 Tiananmen Square Event. One of the repercussions was the blockade on China by the West as well as the international clamors of "China Collapse".

\section{Characteristics and Intrinsic Mechanism of the 1988-1990 Economic Crisis}

It was the 6th economic crisis in 60 years of China's industrialization, the second since the Reform. Judging from its basic characteristics, it belonged to the category of stagnation, due to the expansion of industrial capital driving large investment increment. On that basis it was consistent with classical political economic theory.

During this crisis, economic growth declined from 11.6\% in 1987 to $4.1 \%$ in 1989 , dropping further to $3.8 \%$ in 1990 . Moreover, it was accompanied by the serious 1989 Tiananmen event. Similar to the previous crisis, as economic growth declined, the growth of fixed asset investments, represented mainly by the fixed asset investments of SOEs, also showed a continuous declining trend, from $41.79 \%$ in 1985 to $-8.23 \%$ in 1989 .

In an essay, we have analyzed the process and the dynamics of this crisis. ${ }^{9}$ Here, we would simply expand on the characteristics of this crisis from a comparative perspective.

Looking at the price levels, high inflation was an important characteristic of this economic crisis. The rise in price level was already notable in the second half of 1987 . Entering into 1988, the rise in January was $9.5 \%$, and from then on it rose up month by month, with an average of $1.4 \%$ point in the first half of the year. The government then adopted the suggestion to force through price-marketization reform, and the decision was announced by government media. It gave rise to a wave of panic shopping countrywide, led by profiteer companies related to government officials, with the result that the monthly price levels in July and August

\footnotetext{
${ }^{9}$ Dong Xiaodan \& Wen Tiejun “宏观经济波动与农村治理危机一一关于改革以来 “三农” 与 “三治” 问题相关性的实证分析” (Macro-Economic Fluctuations and Rural Governance Crisis - Empirical Analysis Regarding the Correlation of the 'sannong' and the 'sanzhi' [Governance in Three aspects] since the Reform), 管理世界 (Management World), 2008(9).
} 
rose by 3\% points (Fig. 3). In September the central government, in the third plenary meeting of the 13th National Congress, decided to launch rectification measures, implementing a series of austerity measures to tackle the inflation, such as price control, suppression of investment, tightening of credits, interest rate adjustments and so on. By September the price rise began to slow down but the economy still remained at a state of hyperinflation of $26.7 \%$ (Fig. 3). The retail price index for the year went up to $18.5 \%$ while the purchase price of basic commodities such as industrial raw materials and fuels rose by $19 \%$, the industrial product output price by $20.7 \%$, urban general consumption index by $20.7 \%$. In that year of inflation surge, the quantity of money put into circulation by the state-owned banks reached 67.95 billion yuan, compared to 23.61 billion in 1987 , and just 1.66 billion in 1978 soon after the reform.

Coming hand in hand with inflation, another characteristic in line with classical political economy was a stagnation in production. The main reason was the emergence of chain debts at the end of 1988 caused by rigid austerity measures, with rising interest rates aimed at tackling inflation. The serious debt problem of "triangular debts" emerged. The old causes of "triangular debts" formation were three-fold: first, infrastructure projects had been running substantially over budget while the financial input was insufficient and the financing target was

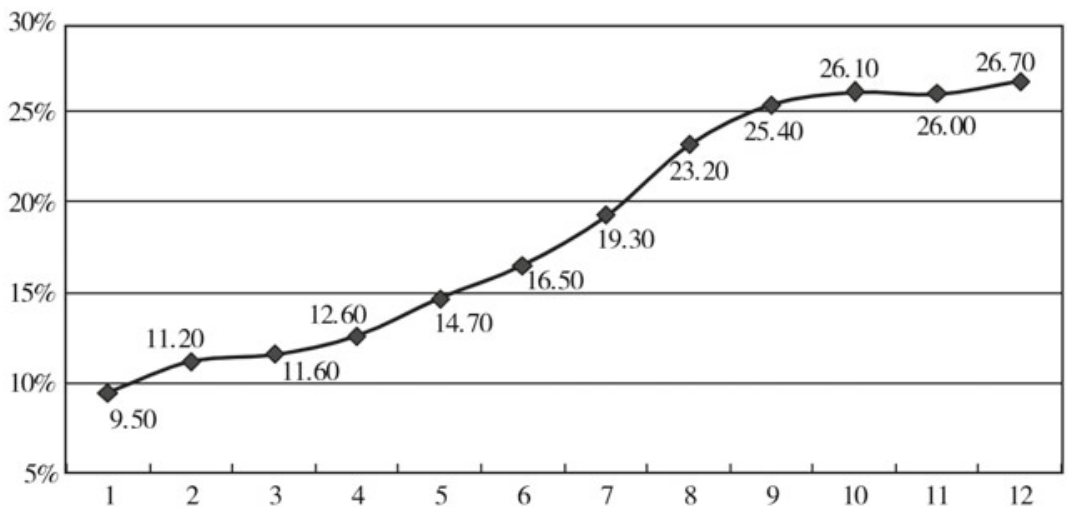

Fig. 3 Monthly rise in price level 1988 
not met. The result were serious shortfalls in fixed asset investments, causing overdue payments to manufacturers and engineering companies; second, the enterprises had serious losses, depleting their capital funds and loans from banks, exacerbating the situation of debt defaults among one another; third, slow sales of products resulted in more funds being tied up in unsold inventory. The overall result was a vicious cycle: input-output goods-high inventories_-arrears-more input-more output-more inventories (Image 4).

A new reason for the triangular debts was the behavior distortion of enterprises under severe scarcity of funds: under the pressure of sudden interest rate surge hence a higher cost of capital, the commercial and retail enterprises that took up most of the liquid funds on one hand protected their own profits by monopolies on wholesale and retailing; on the other hand they put products on consignment and tied up the manufacturers' operating funds. The manufacturers in turn made the same practices on up-stream suppliers of parts and components. At the end, the long-term potential conflict of interests among various state-owned economic sectors rapidly broke the surface and led to the prevalent debts chains around the country.

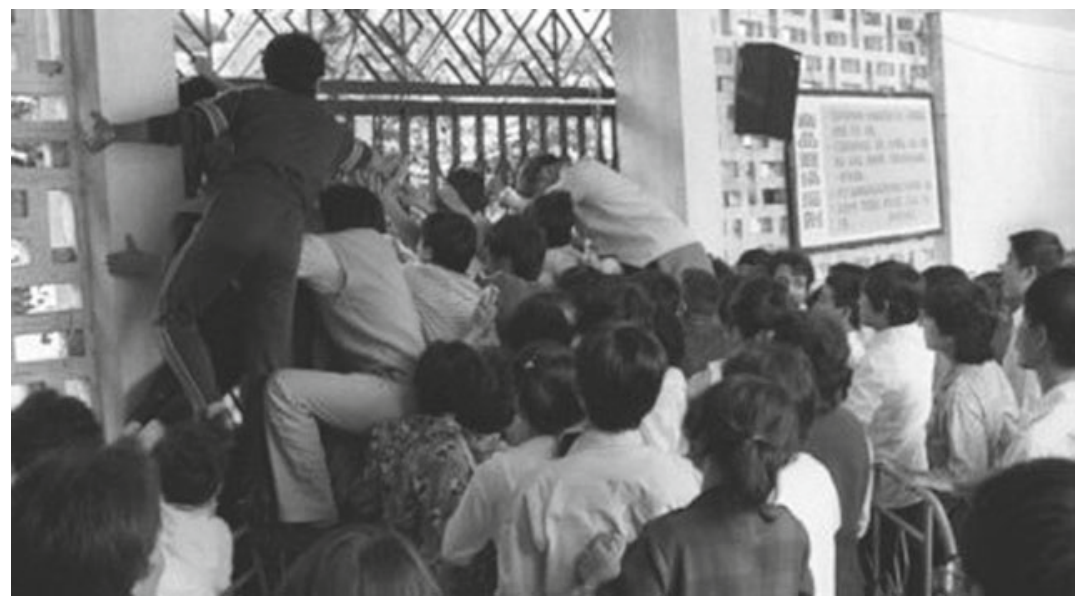

Image 4 Failure of Forcing through Price Reform-People jostling for panic shopping (Source: https://www.21ccom.net/articles/1sjd/ts1s/articks_2001052636 245.html) 
However, the officials involved in policy making back then had lacked experience and knowledge. Official documents simply expressed that what exacerbated the problem of triangular debts had been trade disorders, undisciplined clearing and weak creditability.

Overall, while this crisis had many similarities to the previous one, the fundamental difference lay in the emergence of high inflation as indicated by the annual price index of $18.5 \%$, due to a large expansion in money supply as well as the production stagnation that followed. These characteristics had also been absent in pre-reform economic crises.

In terms of the monetary input structure, the government, under pressure of crisis, had taken from early 1980s the reform of separating the fiscal sector and financial sector with measures such as changing the fund provision to state-owned enterprises from fiscal allocation to loans. After that, given with the overheated economy and high demands of investment and consumption in 1986-1989, the M2 money supply sharply increased with an average annual expansion of 150 billion yuan. The money stock cumulated to 1.2 trillion in 1989 . However the expansion was concentrated relatively in M0 supply. In 1988, the growth of M0 supply reached $46.7 \%$ whereas M1 and M2 increases were only $13.13 \%$ and $22.38 \%$ respectively (Figs. 4 and 5). That meant the new money

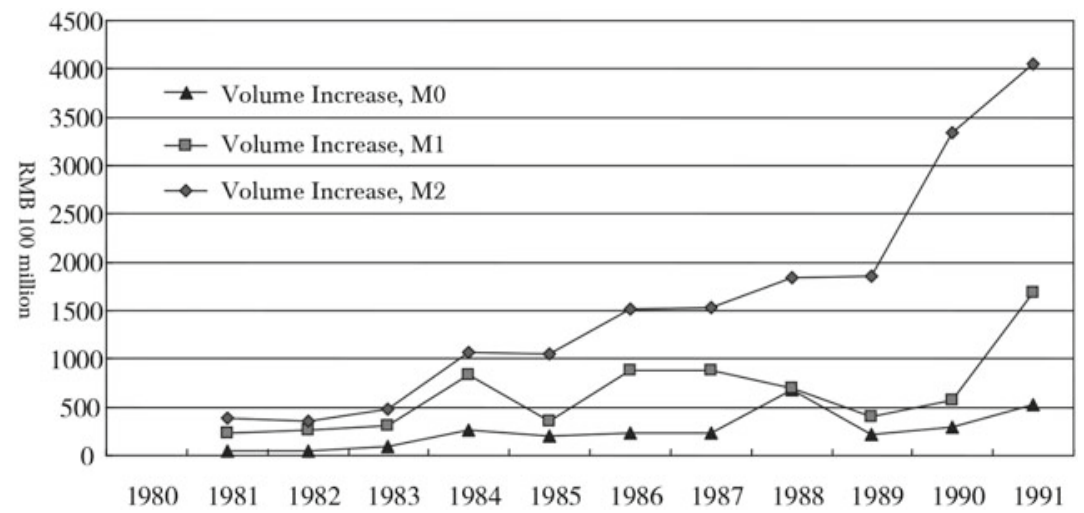

Fig. 4 Money supply volume at various levels 1981-1991 (Source: China Financial Yearbook 1992; China Statistical Yearbook 1992; China Statistical Abstracts 1993) 


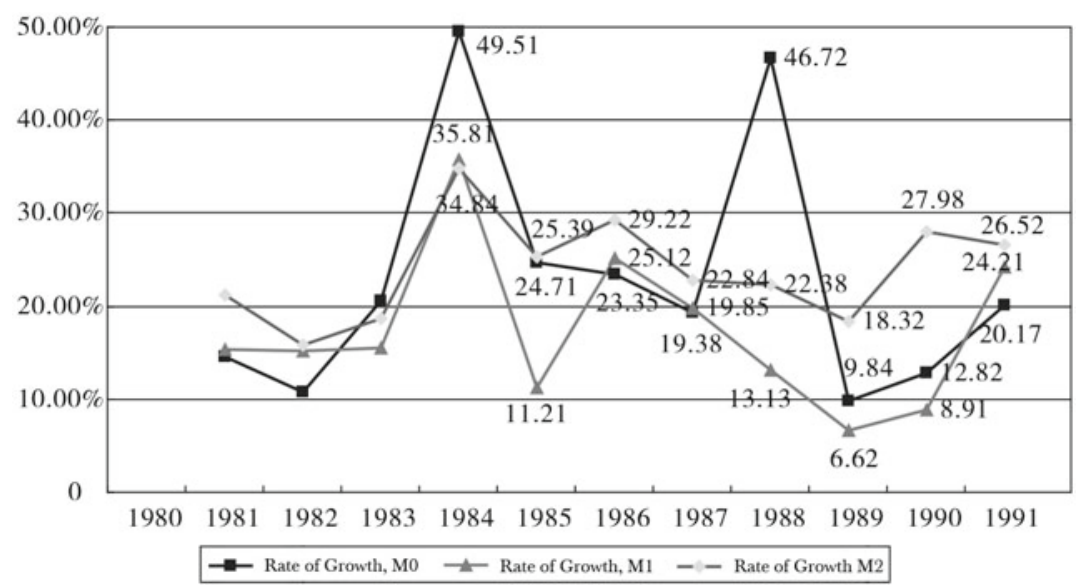

Fig. 5 Money supply growth rate at various levels 1981-1991 (Source: Same as above)

supply in 1988 was mostly in the form of cash. The portion that went into production was relatively small. It added to the inflationary pressure as the demand of goods was higher than supply. The overall demand structure that year provided further evidence on this - the demand for investments grew in 1988 by $16.1 \%$ while consumption demand by $26.5 \%$.

Before the crisis broke out in 1988 , not only did the money supply increase faster than the overall economic growth, the input of fiscal funds had also expanded strongly. In 1986, even though the book amount of budget deficit was less than 10 billion yuan, the total deficit on a comprehensive basis, i.e. including those areas within the fiscal system where revenue was less than expenditures (including domestic debts, foreign debts and fiscal deficit on the book), already reached 20 billion, amounting to $9.8 \%$ of fiscal revenues. The comprehensive deficit rose in 1988 to 30 billion yuan, $14.8 \%$ of fiscal revenues. The fiscal capacity for economic regulation was far from adequate. By 1989, the ratio of comprehensive base deficits-to-revenues reached $25.1 \%$. That means one-fifth of the total fiscal expenditures did not have corresponding revenues. 
If people are willing to analyze China's cyclical economic crisis free of ideology, the 1988-1989 crisis was not essentially different from pre-reform occasions, whether from the perspective of cyclicality or the weight of fiscal deficits.

In summary, the major reasons for this crisis were as follows:

First, under the condition of a "shortage economy", given that the rural industrialization had brought about fast growth in consumption and investment which gave rise to money over-supply, serious inflation was inevitable (Fig. 6).

Second, it had much to do with the radical reform measures adopted by the government, the crucial one being the dual price system reform and subsequently a whole series of pricing marketization reform in 1988, which exposed the enormous hidden institutional costs.

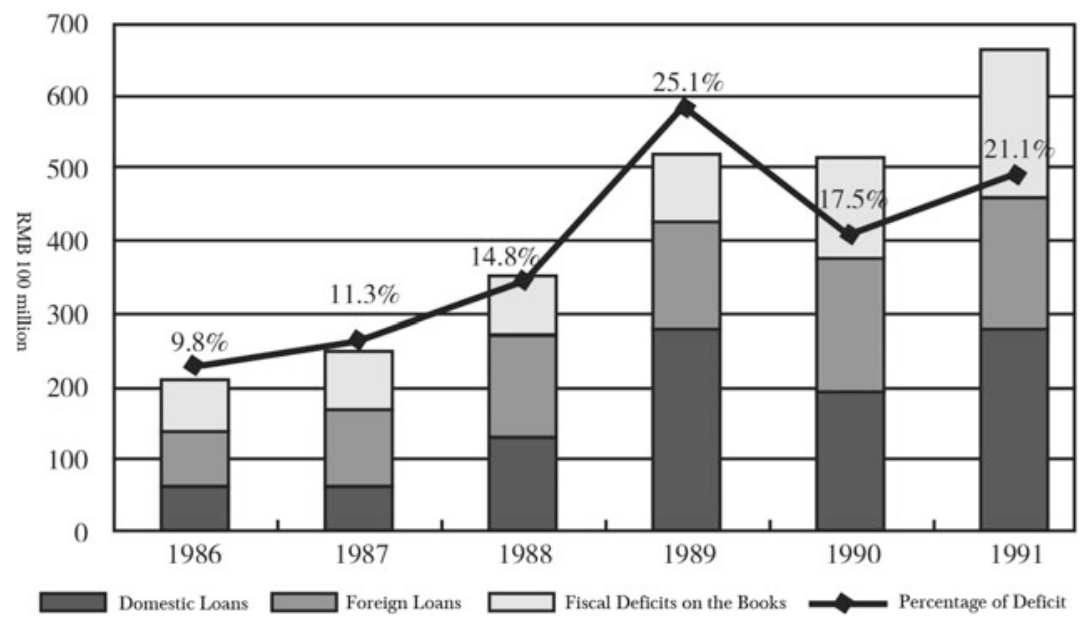

Fig. 6 Budget deficits 1986-1991. Formula: (Book Amount + Domestic Debts + Foreign Debts)/Final Account of Revenues other than lending X $100 \%$ 


\section{Box 4: Decision-Making Process Regarding the Price Reform in 1988}

Going into 1988, several acute contradictions simultaneously exposed indicated the inevitability and urgency of reforming the unreasonable pricing system and price-control. With the State Council's approval, the State Bureau of Commodity Prices and the Ministry of Commerce had decided, starting from 1 April, to adjust the purchase price of certain kinds of grain and edible oil. On 5 April, the State Council promulgated the "Notice Regarding the Trial Implementation of Proper Subsidies to Workers for Major Non-staple Food Price Fluctuation". The subsidies on non-staple food items (meat, eggs, vegetables and sugar) were then changed from hidden to open. After May, the price of color television was allowed to fluctuate and domestic manufactured models generally rose up by $20-30 \%$. With the State Council's approval, starting from 28 July the prices of cigarettes and liquor with famous brands were fully opened and the prices of certain medium rank cigarettes and liquor were raised. At the same time, a systematic scheme to design a price reform was put on the agenda. From 30 May to 1 June, the CPC Central Political Bureau convened the 9th plenary session in Beijing to discuss nationwide economic reform and the economic situation. The meeting indicated that the price and wage system reform required comprehensive consideration and a systematic plan. While it should smooth their relationships and stimulate production, it should also gradually raise the living standard of the majority of the population. The meeting resolved to formulate a systematic reform on price and wage. From 15 to 17 August, the CPC Central Political Bureau convened the 10th plenary meeting in Beidahe and eventually passed "The Preliminary Plan Regarding Price and Wage Reform". The meeting believed that the overall direction of price reform was the state should manage the prices of the few key commodities and the cost of labor, while the prices of most commodities would be open to variations in the market, gradually to realize the objective of "the state regulating the market, the market directing the business". The overall requirement of wage reform was that through raising and adjusting wages and increasing appropriate subsidies to ensure that most workers' living standard would not go down, but instead would gradually improve in line with production development. Furthermore, the principle of income according to work would be carried out to resolve certain unreasonable issues in the allocation of 
wage. This meeting further emphasized that the country's economy was in a period of lively and vigorous development. It would be a favorable time to launch price reform and wage reform. Although problems would be expected yet there would be ample potential and leeway to overcome difficulties. Nevertheless, what happened in reality was far from what was concluded at this meeting.

Now that people could finally free themselves from the old shackle of ideological debates between the "Reformists" and the "Conservatives" and are able to realistically discuss issues that people in that era did not sufficiently understand. The analysis we put forward here would have the originality of going "beyond the left and the right". The government, in an attempt to shrug off the hidden institutional costs of the "dual price mechanism", had pushed ahead the radical price reform. What detonated were two institutional costs previously hidden by the internalized mechanism of the dual-price system: first, the costs relating to rent setting and rent seeking that arose from the collaboration of government departments with bureaucrat profiteering companies; second, the costs relating to marketization giving rise to speculative profits under the conditions of a temporary shortage of goods. Both costs would inevitably have led to high inflation. (In this regard, those who went through the process at the time should have the courage to admit. No one had the foresight back then to foresee what was ahead.)

Thus, when the government was forced to tighten credits in implementing macro-regulation measures, referring to past experiences, it in effect prompted a rift among the interest blocs during the marketization, exposing their contradictions. That in turn led to further deterioration of the chain debts among enterprises.

Even though the government's marketization reform during this period did attain certain result, the national finance was still under a high degree of monopolies by various tiers of governments. The central government, other than reducing money supply and raising interest rates, did not have other financial tools that could regulate local economies (after the tax division reform in 1994, there were even fewer measures that could possibly and effectively regulate local governments.) As a 
result, during this crisis the central government could only exert regulation by reducing fiscal investment to the state-owned industrial enterprises, similar to the approach adopted in the previous case. However, a contraction in investment directly led to depression, characterized by declining economic growth.

\section{The Transferal of the Economic Crisis and the Costs to the Sannong}

The economic crisis that broke out due to the severe inflation arising from the expansion of government credit driven by the expansion of industrial capital, would as a matter of course take place in cities where industrial capital was concentrated. Furthermore, the government responded by the path-dependency of transferring the institutional costs to the sannong. Moreover, the form of transferal was substantially the same as that of the 1979-1980 crisis.

The target of transferal remained the same-the rural enterprises. In execution, the state in the name of the "coastal economic development strategy" requested the rural enterprises to "orient themselves towards overseas markets at both ends of the supply chains", conceding domestic raw material supply and finished product markets to urban enterprises. In addition, the state cut fiscal support to local governments and party organizations, as well as rural public services such as education, health care and so on. Both aspects resulted in peasant incomes declining, hence their consumption. At the same time, the inelastic expenditures of local governments and their affiliated organizations also had to be transferred to the peasants, further adding to their burden. Social tension in rural regions became intensified and the number of mass incidents such as protests and public conflicts increased substantially as a result.

There was yet another outcome with the most significant historical consequence: given that the macro regulation was urban interestsorientated, the rising rural economy and peasant consumptions were to a large extent suppressed. As the peasants comprised the majority of the population, domestic consumption became weak, increasingly intensifying the contradiction within the economic structure. As a consequence, 
it dictated the transformation of the national economy from being domestic demand driven to increasingly export-dependent. This transformation may also partly explain why, upon entering the 1990s, China was so anxious to get incorporated into the globalization dominated by international financial capital.

It should be pointed out that, as compared to previous cases, this time the transferal of the crisis to the sannong brought a notably more adverse impact. As early as in November 1987 when putting forward the coastal economic development strategy, the then Premier had requested the coastal regions to make the best use of their advantages, namely an ample labor supply and the flexibility of rural enterprises, to develop labor intensive industries with the approach of "orienting towards overseas markets at both ends". (That implied making use of foreign capital fund as well as importing raw materials and production facilities. China focused on processing manufacturing.) He believed that Chinese rural enterprises "had the ability to participate in international competition, and should undoubtedly step up to join the export economies." In December that year, the Working Conference of CPC Central pointed out further that in future it would be entirely possible for the rural enterprises to take a share of the international market, as the main form of business operations in China's coastal regions, relying on low-cost labor to produce labor-intensive goods for export. In January 1988, the CPC Central Committee formally published the document expressing this view. ${ }^{10}$

If there had been concrete complementary policies, it might have been considered a proactive policy orientation. Yet most of the politicians and theorists back then could not have possibly realized that under the constraint of the fundamental institutional contradiction in China's rural-urban dichotomy, rural and urban agents each had their own respective predicament, and needed representatives for their respective interests inside the government. The problem was simply that those who represented the urban interest blocs always had much greater influence

${ }^{10}$ See: 江苏省志.乡镇工业志 (Chronicles of Jiangsu Province-Chronicles of Rural Industries). 
on the urban-based governments and their policy decisions than those representing rural interests. ${ }^{11}$

Based on that, the essential context of the urban-rural contradiction in the 1980s during the industrial capital expansion phase was still that same old problem that had emerged ever since the brigade enterprises came into being in the 1970s. The urban enterprises, comprised mainly of state-owned capital and seriously indebted, had attempted to avoid competition with the emerging rural enterprises that had nearly no burden of social cost. Just at the starting point and not yet having accomplished the primitive accumulation of capital, the rural enterprises were facing an array of difficulties in their path of development.

\footnotetext{
${ }^{11}$ During the same period, the State Council Rural Development Research Center and the CPC Central Rural Policy Research Office, the two official faculties representing rural interests at the central decision making level and responsible for issuing the annual Central Document Number 1 on rural policies, had been disbanded upon reorganizations. The agriculture ministry itself could only issue policies within its own scope, not able to coordinate and align relevant policies among other areas such as fiscal, financial, taxation, trade, utilities, and so on. Therefore they could only focus on technicality around agricultural input and structural regulation. In 1991, Fan Xiao Jian, the then head of Collective Economy Directing Department under the Ministry of Agriculture, had personally surveyed around 20 counties on incidents of peasant resistance against excessive levy burden. Yet not only was his report rejected, he had to step aside for nearly ten years without promotion, even though he had been one of the youngest department heads back then. Another person who had spoken up on behalf of Fan about the worsening situation of the sannong was Liao Zhongyi, the Minister of Agriculture. He was criticized and transferred to a lesser post. Without sannong policies and the Document Number 1 that symbolically expressed the central government's intention of guarding peasant interests, the consequence was increasing decline of peasant incomes over 1989-1991, while peasants' cash tax payments kept rising. The number of rural mass protest incidents and violent conflicts grew and the problem of the sannong broke the surface. The author joined in 1993 a survey at a base in Anhui, organized by the Rural Reform Pilot Scheme Zone Office under the Ministry of Agriculture. Most of our team's discussions had revealed that the macro regulation's biased interest orientation was the key factor impacting the sannong. Afterwards, the author published an article in May in Economic Daily, "Support to Agriculture Need to be done Outside of Agriculture", emphasizing that the interests of various departments outside the agriculture realm, such as fiscal, taxation, finance, foreign trade and so on, had impacted the issues of peasants and agriculture. From then on, the author has increasingly focused on the fluctuation and measures in macro-economy and their impact on the sannong.
} 


\section{Box 5: Rural Enterprise's Predicament during the 1980s}

\section{Backward Equipments}

The proposition of brigade enterprise great development was put forward in the Third Plenary of the 11th CPC National Congress in 1978. Ten years later in 1988 the coastal economic development strategy was put forth. During that short span of 10 years, the rural enterprises, especially those in coastal regions, had already made remarkable strides. However, although there were a number of enterprises with advanced technology and state of the art equipments, most of the other were generally backward in technology. In the early days of their development most of them had started by acquiring obsolete machinery from urban industries. For example, more than $85 \%$ of the rural enterprises in Jiangsu Province had pre-1960s equipment. Even in Wuxi where rural enterprises were most developed, only $28 \%$ had equipment made in the 1970s-1980s (1). The backwardness in technology and equipment directly impacted their product quality, and in turn the ability to export, particularly for machinery processing industry which required higher technological standard. For example, the quality inspection of Wuxi's bicycle export in 1988 showed that almost all batches being inspected had problems. In January to May, 3,700 bicycles did not pass the quality control, accounting for $90 \%$ of its total export (2).

\section{Insufficient Funds and Foreign Exchange}

The rural enterprises had been short of funding right from the start. In its early stage, this problem was resolved through the collective economy with the mechanism of "using large scale labor as a substitute for capital". In the later stage it was resolved through financing by the local financial sector with support and direct intervention from the local governments. Even so, the rural enterprise still found it difficult to solve the problem of capital shortage. In particular, the problem worsened at the end of 1988 when the central government started macro-regulation to tackle the economic overheating, so much so that many enterprises went into "triangular debts". Under the circumstances, it was unrealistic for most rural enterprises to solve the problem through domestic financing. The central government had already put forward relevant policies for the enterprises to retain part of the foreign exchange that they earned from 
export. However, since most of their scales were relatively small, it was hard to have sufficient foreign exchange to purchase advanced equipment. Moreover, the reality was that being short of funds the central government would frequently hold back some of the foreign exchange that should go to local regions.

\section{Shortage in Foreign Trade Talent}

Most rural enterprise staff were comprised by peasants from rural regions, with relatively low education level and technology proficiency. With Wuxi as an example, according to 1988 statistics, out of the 11,000 rural enterprises there were only around 600 employees having corresponding technical education and officially certificated as technicians, representing only $0.75 \%$ of total rural enterprise workers (ibid.). Even fewer were versed both in the business and foreign languages. Such conditions were very unfavorable to the development of an exportoriented economy.

It went without saying that the decision-makers on relevant policies were well-aware of these widely known practical problems. Yet in putting forward the policies, they faced the similar problems as in early 1980s - that the economic crisis tightened the supply of raw materials and financing to urban industrial sector, being crowded out by its smaller and more backward rural counterpart. The decision makers again granted priority to the urban sector; the rural enterprises, formerly brigade enterprises were once again confronted with the exclusive policies. Being the direct bearer of the institutional costs arising from the economic crisis, the rural enterprises suffered severe impact on their development, with the outcome of many bankruptcies or closing down.

In any case, the setback in rural enterprise development during this time not only significantly impaired their capacity to absorb rural labor, resulting in the sharp increase of surplus rural labor, depressing peasants' income level, but also depleted the factor of "industry subsidizing agriculture" because of large-scale closing down, resulting at lower agricultural investment and shrinking rural welfare.

References:

(1) Bao Youti (鲍有悌), “三省市乡镇企业发展外向型经济调查” (Survey on the Development of Export-Oriented Economy among 
Rural Enterprises in Three Provinces and Municipality), 宏观经济 管理 (Macro-Economic Management), 1988(9).

(2) Ji Yongming (季永明), “关于江阴市乡镇企业发展外向型经济 调查之系列报告 (续)” (Survey on the Rural Enterprise in Exportoriented Economy Development in Jiangyang Township (cont'd)), 现 代金融 (Modern Finance), 1988(10).

Source: Article published by the author's research team.

Another consequence arising out of this policy was that from 1989 onwards, the growth rate in peasant annual cash income declined for three consecutive years, forcing rural labor to go to cities in search of employment, hence the phenomenon of "migrant worker tide" in the early 1990s. In response, the state began to relax various constraints on the peasants so they could go to cities to work. Since 1988, the state began to allow the peasants to set up service industries and provide various services. The cities were requested to give them favorable terms in providing land and servicing facilities. Urban enterprises were allowed to employ rural workers with permission. The export of labor became a major source of revenues for impoverished regions. Coastal regions with better developed economies as well as large and medium cities were requested to absorb the labor force from impoverished regions in an orderly fashion.

Although in 1989, with a new round of economic austerity measures, the restrictions on the outflow of rural labor force were again tightened, given that the policy of allowing the peasants to go into cities to provide labor and service had been in place for 4 years starting from 1985, it was not possible to stop the flow with just one policy, as in the old days of planned economy. As such, the only feasible measure was to strengthen the management of rural labor migrating.

In the spring of 1992, Deng Xiaoping's Southern Inspection speech prompted the reviving Chinese economy to a rapid surge. At that point, the government further released the regulation on the flow of rural labor. The basic position was to acknowledge, accept and encourage the flow of rural labor towards manufacturing. However, disorderly and unregulated flow would not be acceptable. Various departments were asked to 
work together, adopting multi-facet measures to guide and control the flows. The aim was to direct them to the same or proximal regions and migration to local towns.

The most important measure that collaborated with the relaxation of labor force flow was the cancellation of food vouchers, starting from 1 April, 1992 as a way of alleviating fiscal pressure due to subsidies. With this measure, the peasants were able to procure food as long as they had income. Thereupon the number of migrant workers sharply increased in 1993 to more than 40 million, directly compensating for the declining peasant income due to the close down of rural enterprises.

Very few people have realized that the cancellation of food vouchers due to fiscal pressure had given rise to an even more paradoxical outcome, which was that the Chinese currency resumed its function as a general equivalent for commodities. From then on China entered the era of monetization.

\section{Third Round of Foreign Capital and Debts: Background and Rationale Change-1988-1994: "It is Crucial to Develop Exports to Earn Foreign Exchange"}

In the 30 years from 1949 till 1978 when the economic reform took place, China in Mao's era had gone through two rounds of "opening up": first to the socialist countries led by the USSR in the 1950s; and then to Western capitalist countries in the 1970s following the rapprochement between China and the U.S.A. (The "opening up" in 1977 during the joint leadership of Hua Guofeng and Deng Xiaoping should only be considered an extension and expansion of Mao's policy. However, that round of opening up had to be abandoned due to the 1979-1980 economic crisis, hence not a complete round.) The central government, upon the eruption of crisis caused by heavy debts, was obligated to make major adjustments; having in both cases transferred the costs to the 
sannong. That was the reason why the sannong had been in continuous hardship.

Since the 1980s, Deng Xiaoping, as the core leader of the second generation collective leadership, launched another round of "opening up" with breakthroughs_-bringing in foreign capital gradually to coastal special economic zones and development zones, which then transformed into various export-oriented regions. Since the costs of crisis could not be now simply transferred to the sannong, the contradiction between the centralized state system and various regional interest groups became intensified. Hence, it triggered major structural adjustments in fields from the economy to the politics.

During the early wave of urban economic reform in 1985, urban interest blocs having entrenched vested interests in the accumulation of industrial capital increasingly dominated the design of the Reform and Opening Up policies. Furthermore, they directly prompted the coastal economic development strategy in 1988, driving China into the path of an export-oriented economy.

\section{Box 6: The Central Government's Coastal Economic Development} Strategy

In March 1987, the 5th Session of the 6th National People's Congress officially proposed to gradually shape an export-oriented economy in special economic zones and opened cities and regions along the coast. In the 13th National Congress convened in the same year that direction was further affirmed. Next, in November 1987, the then Premier and Acting General Secretary Zhao Ziyang, during his inspection trip to Jiangsu, Zhejiang and Shanghai, provided a guideline for this new strategy:

"The coastal regions had advantages in climate and geography, and adding to that the support of inland resources. They would definitely be able to develop an export-oriented economy by developing export trade to enter the international market and competition. In doing so, they could stimulate the development of the coastal regions while allowing inland regions to have more of the domestic market share, thereby also stimulating the inland development." (1) 
It could be viewed as the core thinking of the "coastal economic development strategy' formally put forth in the Political Bureau meeting on 6 February, 1988. To implement the strategy, the State Council convened a meeting in Shanghai on 4 March regarding the opening of coastal regions, making concrete plans on execution. It was agreed in the meeting that the key was to promote exports in order to earn foreign exchange. The focus would be on processing manufacturing on a large scale, with raw materials coming from outside and finished products going to the outside. The exports would sustain the imports while imports would nurture exports, hence the integration of imports and exports. According to Tian Jiyun's memoirs, Zhao Ziyang submitted in January 1988 to Deng Xiaoping the report "Regarding the Strategic Issues on Economic Development of Coastal Regions". Deng gave his feedback on January 23: "in complete agreement. Move boldly. Accelerate the pace. Do not procrastinate and miss the opportunity" (ibid.).

Reference:

Tian Jiyun (田纪云), 改革开放的伟大实践 (The Great Praxis of the Reform and Opening Up). Xinhua Publishing, 2009.

There have been numerous discussions among scholars regarding the formation of the concept and substance of "export-oriented economy" in the coastal economic development strategy. Yet up to this day, there is no uniform definition. Different definitions have been given under different contexts and in different historical stages during the formation of China's industrial capital. Tang Jianyu (1988) summarized the theories into three major categories:

- the economic structure theory-export-oriented economy being a state of economic structure, signified by relatively high dependence on exports;

- the operational mechanism theory-a form of economic operation mechanism, denoted by market economy's extent of development;

- the dominant strategy theory-a dominant strategy of an economy with an "export orientation". 
Tang himself believed that the export-oriented economy was an economic development model, a systematic economic whole integrating factors such as economic structure, economic operational mechanism and economic development strategy. With regard to that kind of theoretical controversies and conceptual ambiguities, we could consider it as an inevitable outcome of China's "groping on boulders to cross the river". Yet it was only opaqueness at the surface. If the strategy was contextualized to the background of the era, the rationale discussed earlier for the Reform and Opening up was clear-the strategy of opening up in 1988 was put forth as a tactic for stimulating economic development and alleviating domestic economic problems.

If the substance of the policy was examined in itself, the main purpose would be to promote exports in order to build up foreign exchange reserves, in turn to alleviate the foreign debts pressure. That was because simultaneous to the eruption of the cumulative fiscal deficit crisis in early 1980s, the foreign exchange reserve balance had also turned into deficit, forcing the central government to take urgent measures in response. The shrinkage of foreign exchange reserve was caused by expanding import and rising debts. China's import volume once again surged following the all-round urban economic reform and a greater extent of opening up, as well as the high initiation among regional governments to develop local economy, with the outcome of continuous trade deficits since 1984 . A direct consequence was a sharp decline in China's foreign exchange reserve, from US\$ 8.9 billion in 1983 to US\$2.9 in 1987 (Fig. 7). And in the same period China's foreign debt ratio ${ }^{12}$ jumped from $56 \%$ in 1985 to $77.1 \%$ in 1987 (Fig. 8).

That was to say, in mid to late 1980 s, for every US\$ that China could make from exports, more than a half, even three quarters had to be spent by the state on debt repayments.

It was the two sides of a coin: in a period of capital shortage, under the situation of continuous fiscal deficits and lack of investment capacity, the state could only bring in foreign capital. Yet the increase in foreign debts and decline in foreign exchange reserve would inevitably further add

\footnotetext{
12The ratio of net foreign debts to revenues from export; when a debtor nation does not have foreign exchange reserve or the latter is not taken into consideration, this is a key indicator for measuring debt burden and the risk of foreign debts.
} 


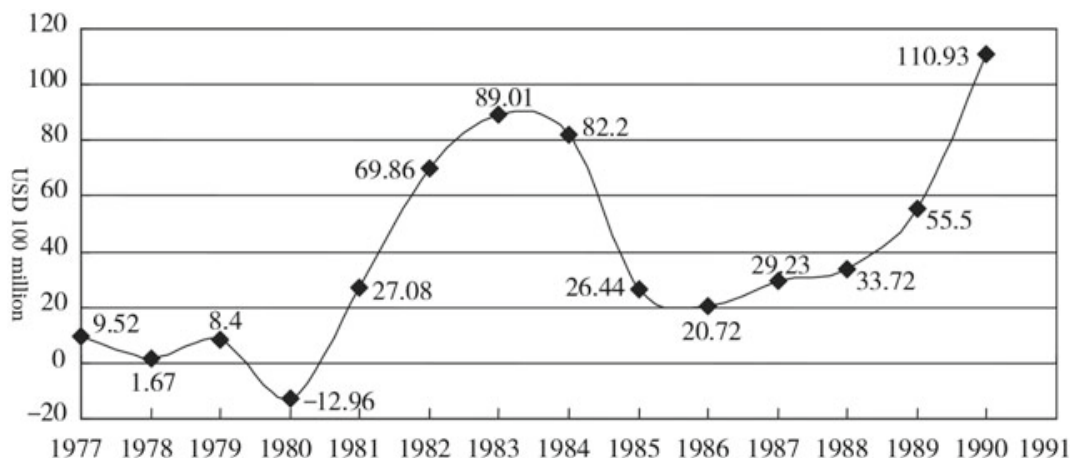

Fig. 7 China's foreign exchange reserve 1977-1991 (Source: State Administration of Foreign Exchange)

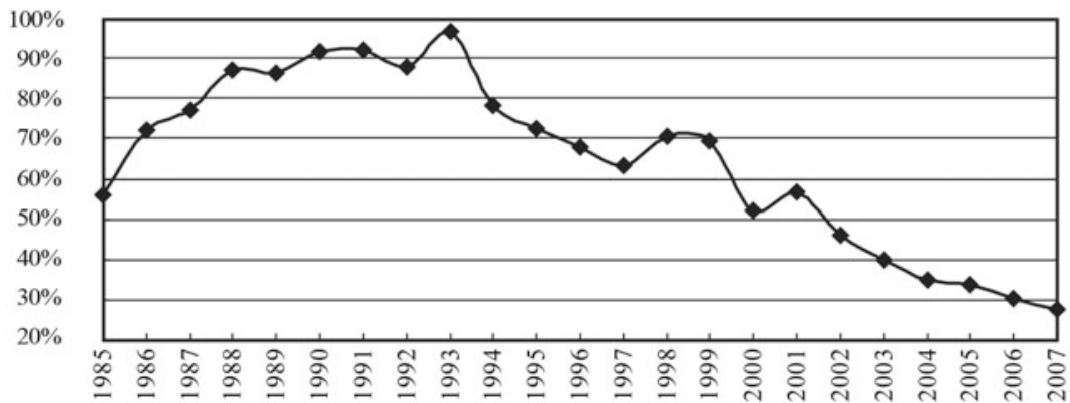

Fig. 8 China's foreign debt ratio 1985-2007 (Source: State Administration of Foreign Exchange)

to the country's fiscal pressure. From this, one would understand why in carrying out the coastal economic development strategy and driving forward the development of an export-oriented economy, the central government emphasized repeatedly that the key was to promote export to earn foreign exchange.

Why this policy was mainly oriented toward the rural enterprises just having started up in coastal regions, far from their completion of capital primitive accumulation? Part of the reasons was due to the needs to protect the state industrial capital. Under the urban-rural dichotomy, it would innately oriented itself towards urban interest blocs. 


\section{Box 7: Wang Jian's Economic Development Strategy Conception of "International Great Circulation"}

Almost simultaneous to the central government proposing the coastal economic development strategy, on 1 November 1987 Wang Jiang, Assistant Researcher of the Economic Research Institute of the State Planning Commission published an essay in Xinhua News Agency's internal reference journal 动态清样 (Dongtai Qingyang [Dynamic Fair Copies]), titled “走国际大循环经济发展战略的可能性及其要求” (Possibility and Requirements of the Economic Development Strategy of International Great Circulation). It was highly consistent with the state's coastal economic development strategy, so much so that when it was published later in the Economic Daily on 5 January, 1988 with the title “选择正确的长期发展战略——关于国际大循环经济发展战略 的构想” (Choosing the Correct Long-term Development StrategyRegarding the conception of International Great Circle Economic Development Strategy), many people thought that the central government's decision had much to do with that paper. Although Wang Jian himself denied that, his paper nevertheless provided a theoretical basis for the strategy.

Wang Jian pointed out that China's overall goal in the next economic development phase should be to move towards a mature industrialized society. To realize this goal, it was necessary to choose the right development strategy; and the basis to consider should be the macro context and the principal contradiction. The macro context for China to move towards a matured industrialized society was that under the condition of a very low per capita income level, and with the situation that China's evolution of industrial structure had skipped the phase of light industries. Even though a relatively developed base of heavy industry had been formed, considering the proportion of agricultural labor, China was nevertheless still underdeveloped.

This highly solidified dichotomy had brought to the strategic choice for the next stage of development a major contradiction of fund allocation between industrial structure upgrade and diversion of rural labor force. It was impossible to continue with the mandatory prohibition over the diversion of rural labor force that had in the past served to accumulate funds for industrial development. In any case, 
if the problem of directing 800 million peasants towards industrialization was not resolved then China could not have truly accomplished industrialization. However, allowing a large number of peasants into non-agricultural sector would reduce the latter's organic constitution, causing the industrial structure to tilt towards light industries, hindering industrial upgrade.

In order to resolve the dilemma brought on by the dichotomy, Wang Jian listed four strategic options: first, give priority to agriculture and light industries in order to fulfill the phase of rural labor diversion; second, make use of foreign funds by lending to fulfill domestic accumulation; third, develop electrical manufacturing for export so that the heavy industries could accumulate for itself through international exchange; fourth, divert the rural labor force into the great international circle by developing labor-intensive manufacturing for export, on one hand resolving the issue of surplus rural labor and on the other hand gaining foreign exchange from the international market.

After analyzing the four strategies, Wang Jian believed that the fourth would be the best choice. To develop with this strategy, he believed there would be three phases.

In the first phase, the effort should focus on developing labor-intensive products for export, such as textiles, food and beverage, household electrical appliances, light industrial goods and so on. The priority should be put on coastal regions given their relatively better conditions. In this phase the development of heavy industry itself would have to be temporarily sacrificed; and the mission of heavy industry at this time would simply be to support the export of light industrial goods. The foreign exchange generated would partly be used to strengthen the servicing capacity of heavy industry and partly for bringing in technologies and raw materials abroad, so as to further develop exports. There would also be a need to improve the infrastructure for transportation and communication, particularly in inland regions, thus creating conditions for export industries to expand to central and western regions. While goods from coastal regions would be exported, goods produced inland would fill the local and domestic markets, laying the ground for exporting in future by upgrading quality. This phase would take 5-7 years. 
In the second phase, inland products would begin exporting to the international market. The capability to earn foreign exchange through labor intensive goods became stronger. A larger portion of the foreign exchange would be used to support the development of basic industries and infrastructure. This phase would take another 5-7 years.

In the third phase, the foreign exchange generated would be applied to develop heavy processing industries that had high added-value. Capital and technology-intensive products would begin to enter the international market. The proportion of labor-intensive goods would decline. The pressure from labor diversion would also decline. Employment would begin to shift to heavy processing industries. All these would signify the arrival of China's industrial structure upgrade as well as high-speed growth. This phase would probably begin only towards the end of the ninth Five-Year Plan.

Wang Jian's analysis at that time had been very objective with foresight. Its impact on the central government policies had also been quite direct.

However, would the coastal economic development work out in real life the way it was conceived to forge an export-oriented economy through rural enterprises? In this regard most analyses from theoretical studies thought it was unrealistic. Nevertheless very few people had directly expressed dissenting opinions on the central government's strategic goal. Instead, most had expressed their views through direct responses to Wang Jian's idea of "international great circle".

Based on the contents of the discussions back then, people had valued highly Wang Jian's exploration of China's future economic development. Yet most researchers had doubts about the feasibility of the "international great circle” (Yang Peixin (1988), Wei Dakang, Gao Liang (1988), Liang Guiquan (1988), Yan Jinmin (1988), Min Jianshu (1988), Cai Wenxiang (1989)).

The focus was mainly on a whole series of difficulties that existed in rural enterprises: could labor intensive products, being low-end goods, be able to exchange into the international market for sufficient foreign currencies to support the development of heavy industries? How would the rural enterprises, most of them with backward technology and equipment, as well as little foreign trade experience, realize the strategy as 
prescribed? Under continuous inflation, how could the rural enterprises gain the impetus on export-oriented development?

Furthermore, from the perspective of enterprise echelons, the main force to develop export-oriented economy should be the urban large and medium enterprises and foreign trade enterprises. That was because compared with the rural counterparts, the urban enterprises were superior in terms of management quality, organization, technological know-how, resources efficiency, scale of economy, industrial-chain effect, risk-bearing and so on. If the urban large and medium enterprises were given more autonomy in their operations and the right to export, they would be able to become the leaders driving rural enterprises to form conglomerates and organizing the export-oriented processing manufacturing.

It goes without saying that such obvious, commonly known real life issues were well perceived in the minds of decision-makers. Still, when the policy was introduced, the main intention became a realistic resolution about the contradiction between coastal and inland regions over raw materials and domestic market. The coastal regions were requested to develop an export oriented economy with "both suppliers and markets abroad".

Source: Wang Jian "Choosing the Right Long-term Development Strategy-Regarding the conception of International Great Circle Economic Development Strategy".

Actually, since 1958 when the urban-rural dual structure was formerly established, internal contradictions of this sort in policy making had never ceased. The problems facing Chinese decision-makers in 1988 were similar to those in early 1980 s with controversies such as "the small crowding out the big" and "the backward crowding out the advanced". The crux was still the urban industries once again got in a bind in the supply of raw materials and funds. Looking at the policy that finally came out, one found the same consideration of prioritizing urban industries. As a result rural enterprises (formerly brigade enterprises) were being discriminated once again. The argument that "coastal regions and inland regions had fought over raw materials and market" was no more than a 
pretext hiding the fact that urban interest blocs dominated the reform policies making.

The various issues around export-oriented coastal economy and the national development strategy were well worth of further reflection. But no matter what, the promulgation of the strategy to focus on export-oriented processing manufacturing on a large scale, trumpeted the commencement of the export-oriented economic development with Chinese characteristics by non-state-owned enterprises.

What came next was another important year, 1994, when there was a large devaluation of the Renminbi in one shot, accomplished by converging the official and the market exchange rates in the name of marketization.

Since the time of the Opium War in the nineteenth century, China recorded its last instance of major trade deficit in 1993, with the outbreak of major deficits in two other sectors. What helped ending the large trade deficit of US\$12.2 billion in 1993 was partly the decision in 1992 to open up more selected cities around the country after the economic crisis in 1988-1991. Another more direct reason was the 1994 foreign exchange reform which was executed under the pressure of balance of payments deficit with a one-time devaluation of the Renminbi to USD exchange rate by more than 50\% (Fig. 9).

The substantial devaluation amounted to artificially creating a huge basin for the global capital liquidity. It meant that Chinese enterprises, then not yet competitive in the international market and still under

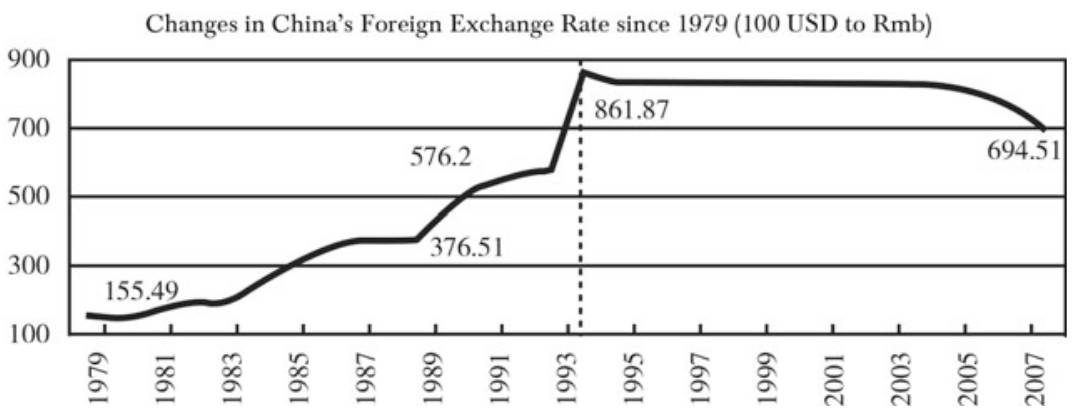

Fig. 9 Renminbi exchange rate since 1979 
a blockade imposed by the West due to the June Fourth Incident in 1989, were abruptly and unexpectedly given an enormous cost advantage. Moreover, with the expansion of financial capitalism and another round of international industrial structure upgrading towards the end of the 1990s, China's export trade situation underwent an immense change within a few years.

In 1994, China's trade turned from deficit to surplus, and since then trade surplus has gone up year after year.

\section{The 7th Crisis: 1993-1994, the Third Economic Crisis since the Reform, and the Transformation to Export-Oriented Model}

In 1992-1993, the central government, in an attempt to accelerate the monetization and the opening up of the capital market, was obliged to take full liability for the high level of foreign debts arising from the overheated economy. Because of that, the 1993-1994 economic crisis soon broke out-major deficits simultaneously in three aspects: fiscal, financial and balance of payments, which wreaked serious damage. It had not been long since the 1988-1990 crisis. The external situation was also harsh, with the blockade by the West still in effect and the recent disintegration of the USSR. The idea of the coming "China's collapse" became a fad in the international media. At this time, the third generation collective leadership just formed a relatively centralized leadership system, and needed to put a curb on the reactions in the society by resorting to an iron-fist approach, with enormous costs to both urban and rural sectors. Only then was China able to stumble out of the shadow of crisis.

Such was the objective context of that era when people blamed everything about crisis on the "old system" and advocated radical marketization reform. After that, given that the radical reform had resulted in an even higher degree of external dependency for China's economy, the third generation leadership core then went along with the trend and decided to accelerate China's integration into globalization. 


\section{Internal Mechanism and Characteristics of the 7th Economic Crisis in 60 Years of Industrialization, the Third since the Reform}

Unlike the previous two crises generated due to a surge in domestic demand, the 7th economic crisis in 1993-1994, in which the three major deficits occurring simultaneously with the large expansion in money supply giving rise to a staggering CPI of $24.1 \%$ in 1994 , was not only closely linked to the deepened reforms as a response to the depression caused by previous regulation, but also the first instance of economic crisis caused by speculative demands since the reform.

When China was in depression in 1990-1991, there were controversies around the Reform. Some who did not have sufficient understanding on the cyclical pattern of economic crises blamed the Reform, while others with specific purposes in mind, mainly those supporting Deng's Southern Inspection Speech, advocated deepening the reform. Such controversies seemed similar to past ones regarding the "left" and "right" line struggles. Perhaps they had diverted people's attention from seriously learning the experience and lessons from the failed attempt of forcing through the "price reform". When economic revival emerged in 1991-1992, people swiftly started to take part into the newly established speculative markets of stocks, futures and real estates. The further liberalization of these speculative markets which had higher capacity to absorb funds than general goods and production factor markets stimulated a surge in China's GDP. The Chinese economy seemed to have jumped through the stage of recovery directly into a boom.

This coincided with the affirmation in 1992 by the CPC 14th National Congress that the goal of the Reform would be a new market economy. Thereupon all kinds of interest blocs, including bureaucrat profiteering companies (profit-making companies previously set up by various government units to provide employments to the adult children of the officials) that had made their first bucket of gold taking advantage of the dual-price mechanism, jostled into the bonanza in the name of the Reform with political correctness, but in fact aimed at reaping personal gains and wealth. Within a short span of time, the aggressive expansion in fixed asset investments nationwide as well as the 
continuous disorder in the financial sector steered the Chinese economy towards high growth, as measured by GDP.

If people would leap beyond the binary ideological framework of reformist versus conservative, they could easily identify two systemic characteristics of China in the 1990s similar to those before the Reform-first, the institutional malady of economic regulation still lay at the dilemma confronting the old model in 1958 when the state conceding power and interests tier by tier: either economic disorder as a result of concessions or immediate recession if power was once again centralized; second, the dominating mechanism for fast economic growth during industrial capital expansion was still the urge towards crude and extensive growth.

Two intrinsic contexts should be noted about the investment frenzy of early 1990s that took place under such institution and mechanism:

First, in 1992 the new system of market economy was set as a goal and Premier Li Peng signed a document, "Regulation on the Transformation of Industrial Enterprises Operation owned by the Whole People". It clearly required the orderly moves of those enterprises into the market. Then the policy of "separating the government and the enterprises" promulgated by the central government further gave rise to the frenzy among official departments to set up their affiliated businesses. In 1992 alone, more than 200,000 companies were set up. As soon as these new capital interest blocs came into being, with their intricate connections to the government, they strengthened the process of primitive capital accumulation through rent-setting and rent-seeking. The institutional costs intrinsic to that abuse of power, transferred smoothly to the whole society by their privilege, was a powerful factor that drove the 1993-1994 economic crisis. This kind of institutional transformation, as Justin Lin Yifu said, resulted simply at turning government departments into companies. Apart from changing the titles of management personnel and removing government restrictions on their remuneration, the fact that their survival relied on administrative monopoly and favorable government policies basically remained unchanged. ${ }^{13}$

\footnotetext{
${ }^{13}$ Justin Lin Yifu, “企业自生能力与改革的深层次问题” (Enterprises' Ability of Self-reliance and the Profound Issues of the Reform), 国研网 (National Research Network), 2002-03-28.
} 
Second, after Deng Xiaoping's Southern Inspection Speech, there was large scale expansion in investments around the country, in the name of "development is the hard-core truth". The real estate frenzy, the development zone frenzy and the development project frenzy that prevailed everywhere all drove the frenzy in investment and financing. The concession by the authorities gave birth to diversified agents, multilevel decisions on projects, and myriad sources of funding. However corresponding standards and regulating mechanisms were yet to be established. The outcome was increasing difficulty in suppressing the drastically expanding investment desire. Money was needed to expand investments, hence the mass financing activities as well as the fights for funding through high interest rates. All kinds of bonds, cash coupons and self-made stocks were on offer at increasingly high interest rates, generally as high as $20-40 \%$. Yet the rate of growth in savings was slowing down and even became negative in many regions.

Under such a chaotic situation due to local authorities' autonomous pursuits of "development", the central government, in an attempt to sustain the operation of the financial system, could only increase money supply by an excessive amount. The volume of new money supply in 1993 was 152.87 billion yuan and in 1994142.39 billion (Source: China Financial Yearbooks).

Even with the large expansion in money supply by the central government, many regions still had cases of payment troubles. More than ten provinces had called the Party Central Committee or the State Council to report that they were short of fund. Inland banks had the worst problem. Therefore, various kinds of notes in lieu of cash payments were commonly used.

At this point, most of the financial institutions nationwide recorded "financial deficits" - loans more than deposits—which in turn prompted higher supply of money and exacerbated the prospect of inflation.

A severe shortage of funds had led to abnormally high price to start with. The deep differential between official and market interest rates added to the problem. Rent-seeking activities therefore became increasingly rampant. Consequently, the operations of financial institutions 
were in a state of chaos. The state-owned banks set up numerous companies in securities, real estates and various investment trusts with myriad titles. Large amount of funds were diverted from the banks to those companies. Most of the banks also participated in real estate development projects, security trading and so on, taking up the funds available for turnover. Furthermore, there were the bureaucrat profiteering companies that wielded havocs in the markets, speculating on stocks and bonds, using state's money to reap private gains.

\section{Box 8: Stock Markets Resumed in China}

As symbolized by the opening of the Shanghai and Shenzhen stock exchanges in 1990 and 1991 respectively, China’s stock markets officially resumed and gradually became an indispensable part of China's economic system. Some people said it was China's "greatest revolution" in the financial sector in the last decade of the twentieth century. The establishment of the securities market set up a larger arena for China's financial capital. The flow of funds into stock markets through varied channels became an obvious trend. It marked the beginning of the new era in which China's financial capital was alienated from industrial capital. The expansion of the financial market begun with China's currency becoming capital and its generation through credit-creation.

At the end of 1999, Qin Xiao, General Manager of CITIC, talked about the process in his speech at Beijing University Economic Research Center, "The Alienation of Financial Industry and the 'Virtual Economy' in the Financial Market". Following the appearance of stocks and bonds, currency became a kind of financial investment vehicle, i.e. the capitalization of currency. That was also when money was being generated through credit-creation. The creation of money through creditcreation and its transformation of into capital was the early state of a virtual economy. It no longer had a correlating relationship with the physical economy, but instead was an outcome of credit expansion.

During this period when financial capital gradually became alienated from the real economy, those companies having government connections were able to enter the primitive capital accumulation phase and in turn 
made an impact on the related government departments causing chaos in economic management.

Ever since the tax division reform that started in the 1980s and altered the allocation of tax revenues between the central government and local governments, local recklessness had emerged in three areas-levy-fees, fines, and fund-raising. The years 1983-1984 saw the first wave of government employees going into business. Then the second wave was in 1986-1987 and the third round started in 1992 with Deng Xiaoping's Southern Inspection speech. Yet since the third round with the simultaneous opening of the three speculative markets, the "recklessness" now turned into disorder- reckless financing, reckless (short-term) lending, and reckless setting-up of economic entities.

Back then people summarized this phase of economic overheating vividly as the "four fevers" (real estate fever, development zone fever, funding fever, stocks fever), the "four highs" (high investment expansion, high industrial growth, high monetary expansion and lending, high inflation), "four crunches" (transportation, energy, raw materials supply, funds supply) and finally "one chaos" (chaos in economic order, especially in financial order). Such chaotic phenomena in the local economies that happened after 1992 were similar to those during the "Great Leap Forward," a result of the central government conceding power to the local governments as an attempt to stimulate the latter's initiative in carrying on industrialization. The institutional costs of the 1958 chaos had transformed into the 1960 crisis which had to be borne by the entire society. Similarly, the institutional costs of the 1992 economic disorders also transformed into the crisis of 1994. A high inflation of over 24\%, widespread lay-offs of SOE employees, large-scale expropriation of land from the peasants, sharp increase in mass incidents and so on-all that had been caused by the primitive accumulation of capital by interest blocs, giving rise to disorder in the economy, and the enormous institutional costs of which were inevitably transferred to the whole society.

The successive fiscal deficits and abnormally high money supply immediately detonated the inflation crisis. Furthermore, because of overheated investments, China's external economic relations were also being seriously challenged. In the 170 years counting from the Opium War of 
1840 to the year 2010, the last instance of a severe foreign trade deficit emerged in the year 1993 when there were major deficits simultaneously in three realms. The accumulated balance of payments deficits handicapped China's foreign exchange reserve system. At the end of 1993, China's foreign exchange reserve was US\$21.119 billion. Taking out the short-term liabilities of US\$ 13.55 billion, the balance was US\$ 7.65 billion, not even sufficient to cover the trade deficit in that year (US\$ 12.2 billion), not to mention the accumulated trade deficits since the 1980s (totaling US\$ 38.46 billion by the end of 1993) as well as long term liabilities of US $\$ 70.027$ billion). Total foreign debts accounted for $13.9 \%$ of GDP in 1993, compared to the proportion for fiscal budget of $12.56 \%$ !

Based on the foregoing, people should deduce de-ideologically from China's essential experience as a developing country-Deng Xiaoping, by path-dependency, had inherited the 1970s' experience of bringing in foreign funds under Mao Zedong and Zhou Enlai. This third round of foreign investments in the 1980s, mostly brought in by local governments without having to bear the associated risks, resulted in an accumulation of foreign debts, which became the central government's liabilities. The foreign debt volume in 1993 reached a historical high since the establishment of New China.

The "three major deficits", other than the balance of payments deficit, also included the fiscal deficit that was directly borne by the central government, as well as the "banking deficit" i.e. minus capital funds in the state-owned financial sector, with serious negative differentials between deposit and loan (Fig. 10).

The simultaneous deterioration of the three major deficits gave no choice to the central government other than launching macro-regulation again in the summer of 1993.

On 24 June 1993, the CPC Central Committee and State Council promulgated the document "Regarding Current Economic Situation and Strengthening Macro-regulation", with important directives on "grasping the opportunities in economic management, speeding up the development; at the same time emphasizing reliability, avoiding loss, especially 


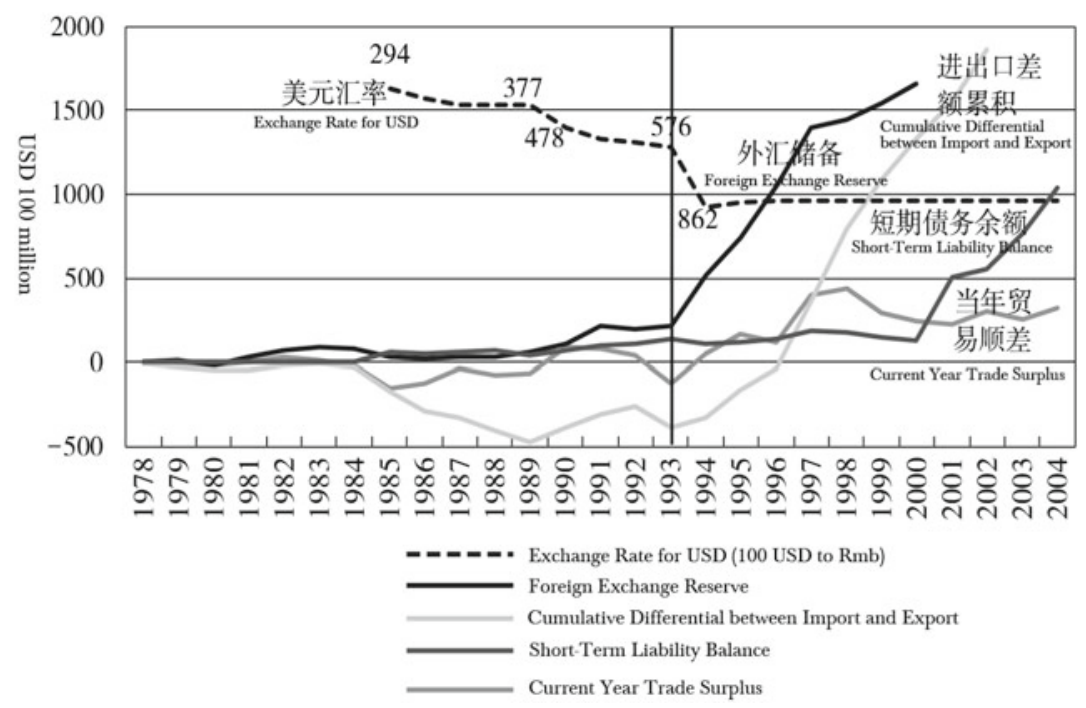

Fig. 10 Background of China's foreign exchange reform in 1994

big loss". The focus on speeding up development would involve deepening the reform, transforming the mechanisms, optimizing the structures and raising effectiveness. Furthermore, it put forth sixteen measures on strengthening and improving macro-regulation, with strict control on monetary expansion and stabilization of the financial situation.

The wordings of these documents that went into the official record were somehow gentle and proper. Yet back then they were referred to as the "sixteen iron-and-blood articles". That was because these macroregulative measures aiming at accelerating marketization reform would "draw blood like a knife".

Indeed, 1994 was generally recognized as the "reform year". During this year, the government, in the name of Reform, put forth three major macro-economic measures to deal with three respective major deficits:

First, foreign exchange reform:

Accomplished exchange rate adjustment at one stroke by one-time $57 \%$ devaluation of the nominal exchange rate of the RMB. The exchange rate of Renminbi against USD was dropped from 1: 5.64 
to $1: 8.27$ as a way to stimulate exports and alleviate the quagmire of international payments.

Second, expansion of credit:

With successive years of fiscal deficits, the state financial sector was severely overdrawn, to the extent that the capital funds of state-owned banks were completely depleted and even part of the deposit funds were used up. In addition, there was enormous domestic demand during this stage arising from the investment frenzy. There was no other option but to substantially increase public debts and expand money supply.

Third, taxation system reform:

To alleviate the central government's fiscal difficulty, the system of fiscal responsibility by various tiers of local government established in 1984 was further transformed into the tax-division system. This reform altered the proportion of fiscal revenues division between the central and regional governments, from more than $70 \%$ to local governments down to $50 \%$, a substantial cut. The consequence was local governments taking to generate revenues from selling land in a frenzied manner in order to compensate for the shortfall in fiscal revenues (Figs. 11, 12, and 13).

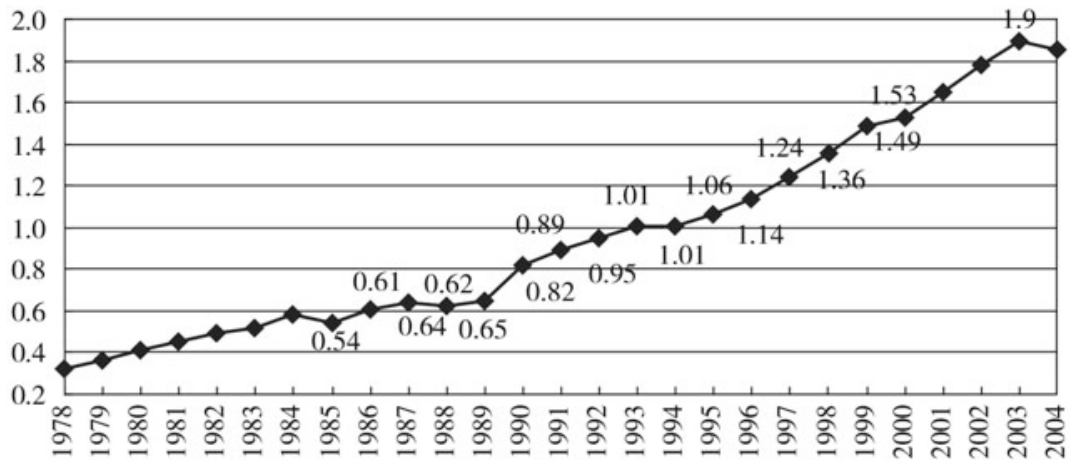

Fig. 11 Real M2/GDP 1978-2004 (Source: Han Ping (韩平), Li Bin (李斌) \& Cui Yong (崔永) “我国 M2/GDP 的动态增长路径、货币供应量与政策选择” (M2/ GDP Dynamic Growth Path, Money Supply and Policy Options in China), 经济研究 (Economic Research), 2005[10]) 


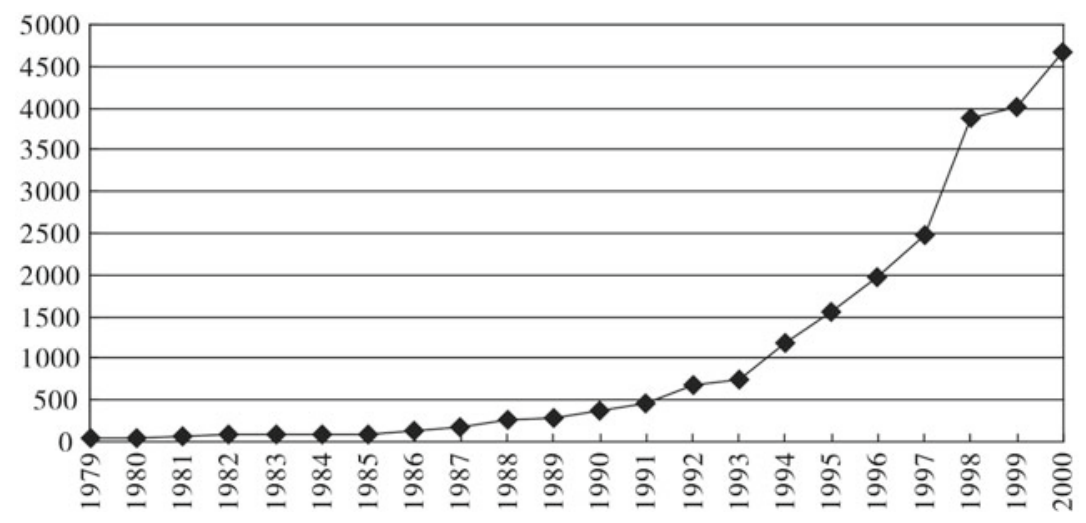

Fig. 12 Volume of national debt issued 1979-2000. Unit: 0.1 billion (Source: Li Biao (李彪) \& Lu Zhihong (卢志红) “我国国债发行规模中的协整和 ECM 实证分析” (A Co-integration Analysis and ECM Empirical Analysis on China's Debt Issuance Scale), Journal of Anhui Agricultural University (Social Science), 2004[4])

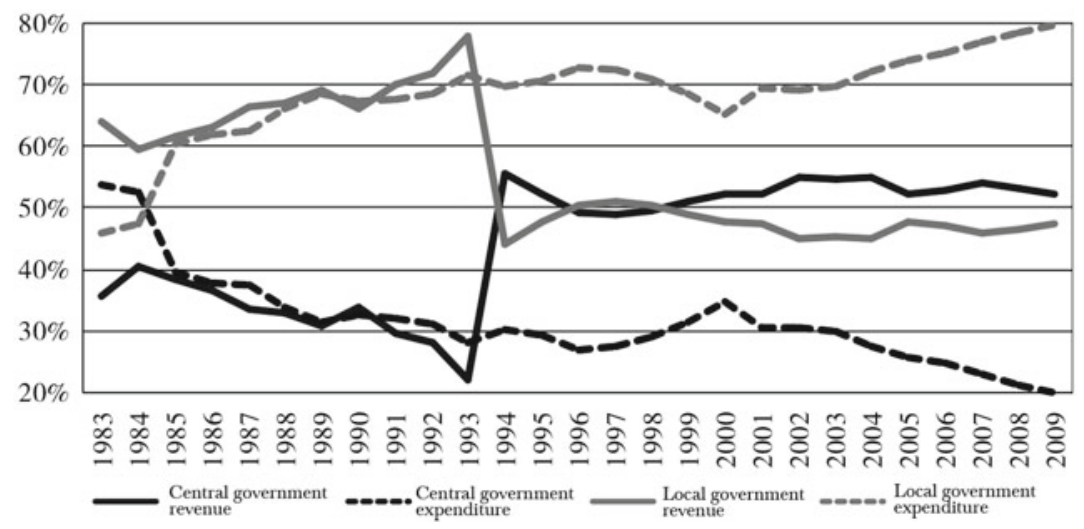

Fig. 13 Proportion of fiscal revenues and expenditures between the central and local governments 1983-2009 (Source: China Financial Yearbook 2002)

In addition to these three major macro reforms, the decision makers further launched the state-owned-enterprise reform, with the consequence of China's social structural contradiction becoming increasingly accentuated. Given that the total fiscal revenues of the central and local governments declined to a historic low level of $11-13 \%$ of GDP 


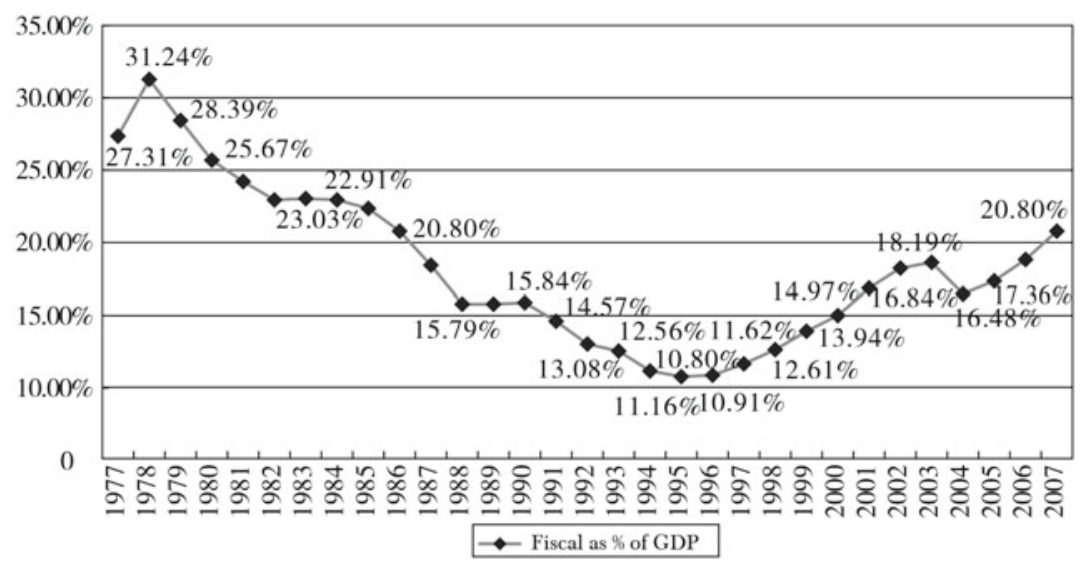

Fig. 14 National fiscal revenue as percentage of GDP 1997-2007 (Source of data: China Statistical Yearbooks)

(Fig. 14), local governments high-handedly forced through this reform mainly by selling off state-owned enterprises. The result was large scale lay-off and dismissal of SOE employees in tens of millions with little compensation for their tenure. And most of them had not been in time to be included in the social security and medical care coverage. There was a reduction during 1995-2000 in staff of 48 million just in state-owned sector and township collective units. ${ }^{14}$

The central government had already proposed macro regulation in 1993 amid the overheating. Nevertheless, the formal launching of the tax division reform in 1994, while well-intended, objectively made it hard to effectively implement the macro regulation.

Within the new taxation system, the local governments only had two main sources of revenues under their control - the profits realized from cashing in land and the increase in tax revenues from expanding foreign investments and urbanization, leading to higher income tax, business tax from construction and real estates. These tax categories were entitled to

\footnotetext{
${ }^{14}$ Wang Shaoguang (王绍光), Hu Angang (胡鞍钢), Ding Yuanzhu (丁元竹) “最严重的警 告: 经济繁荣背后的社会不稳定” (The Most Serious Warning: the Social Disability behind Economic Prosperity), 战略与管理 (Strategy and Management), 2002(4).
} 
local governments. ${ }^{15}$ Under the pressure of inelastic fiscal expenditures, land became the main source of revenues that could be realized in the shortest period of time. "Generating money with land" thus became a widespread local government practice subsequent to the tax division system reform.

Another aspect was that as a part of the reform, the tax revenues collected by local governments in 1993 would be taken as the benchmark for the central's fiscal allocation to the local in future years. Using 1993 as the benchmark year, the year before the new system was actually launched, was a "deal" with local governments in exchange for their support. What happened was that in the few months after it was announced, there were abnormal surges in the amount of tax collected by local governments countrywide, including ad hoc impositions, collection of long-overdue taxes, even taxes owed by enterprises that were already closed down. The increment in local tax revenues in 1993 was 96.66 billion yuan or a $40.2 \%$ growth, out of which 75.7 billion were collected from September to December, with a growth of 51.8, 62.5, 86.1 and $121.3 \%$ respectively compared with the same month last year. ${ }^{16}$

It became a key factor determining the success of the new system, which depended on whether the local governments could keep up the high growth in tax revenues in 1994. If the macro-regulation measures were strictly executed, they would definitely be handicapped. Hence, much had been said but little was actually done. In this regard, the then Minister of Finance Xiang Huaicheng commented that "a strong support from local governments is essential to drive major taxation reform. Compromise was inevitable. The price had to be paid. The concession has won over the people, united their minds and assured the smooth launching of the tax division reform" (ibid.).

\footnotetext{
${ }^{15}$ Jiang Xingsan (蒋省三), Liu Shouying (刘守英), Li Qing (李青) “土地制度改革与国 民经济成长” (Land System Reform and the Growth of National Economy), 管理世界 (Management World), 2007(9).

16 Source: Xiang Huaicheng (项怀诚) \& Ma Guochuan (马国川) “改革是共和国财政六十年 的主线 (上)” (Reform was the Main Line for Fiscal Finance over Sixty Years of the People's Republic [Part 1]), 读书 (Doushu), 2009(9).
} 
In this way, amid the repeated game playing between the central and local governments, the former announced in 1997 that a "soft-landing" had been successfully accomplished.

On 23 January 1997, the State Statistics Bureau published the article "Macro-regulation achievements have been notable and structural optimization is imperative-economic situation of 1996 and prospect for 1997", pointing out that with dedicated effort by all sectors, the national economy was operating well now; the "soft-landing" was basically successful; economic growth had gradually and smoothly declined from the peak of $14.2 \%$ in 1992 to $9.7 \%$ in 1996, on average around one-percent drop every year; price level increase had dropped from the high of $21.7 \%$ in 1994 to around 6\% in 1996, a total drop of 15.7 percentage point. ${ }^{17}$

These macro-regulation measures also resulted at a much higher dependency of China's economy on export. In 1994 when the Renminbi was devalued at one stroke by over $50 \%$, China attained the historical record of US\$121.01 billion in export, a growth of $31.9 \%$ from previous year. If the growth rate was calculated on Renminbi basis, it was even more staggering at $97.3 \%$.

Indeed, these measures also led to weak domestic consumption and a rapid decline in domestic demand. On one aspect it motivated various local governments to eagerly bring in outside investors, thereby stimulating the momentum for internal structural adjustments. Objectively it was also a response to the transnational corporation's needs amid their structural upgrade in terms of financial capital to acquire strategic industries in developing countries. On another aspect, it was also one of the main reasons that impelled the mainstream policy makers and researchers in China to embrace economic globalization with enthusiasm, thereby speeding up the pace of China's negotiation with the WTO. The foreign economic and trade sector formally proposed in their documents "the strategy of going global". In 1994, China's oil industry went abroad for the first time - the Sinopec Group signed agreements with six countries to participate in their oil and gas projects, including Iran, Saudi Arabia,

${ }^{17}$ Liu Guoguang (刘国光) \& Liu Shucheng (刘树成) “论软着陆” (On Soft-landing), People’s Daily, 7 January 1997, page 9. 


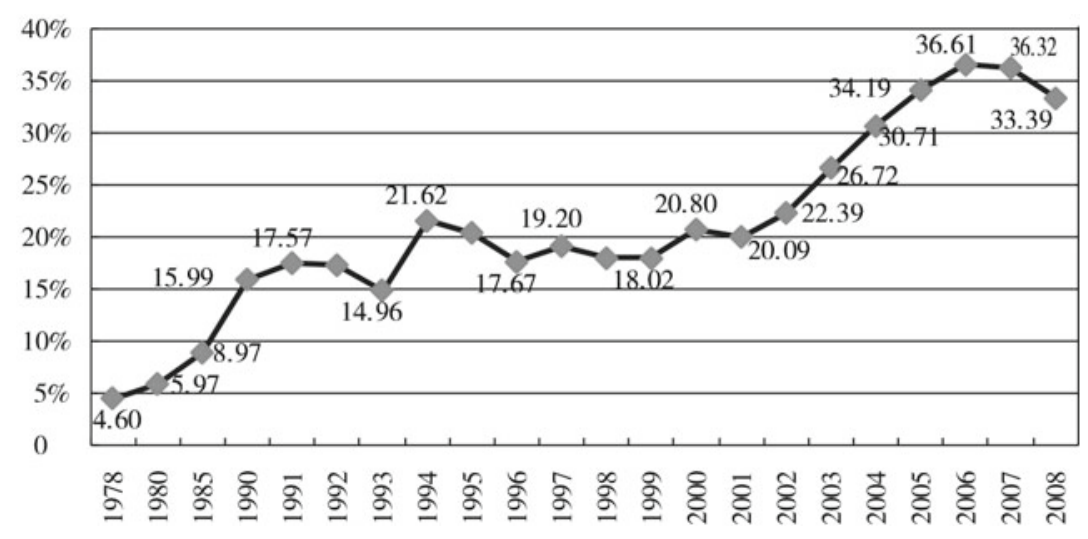

Fig. 15 Export as \% of GDP in China 1978-2008

Gabon, Kazakhstan, Yemen and Ecuador, as well as an agreement with Saudi Aramco and the Ministry of Energy of Saudi Arabia on natural gas prospecting and extraction in Block B area of the Rub al-khali Basin.

The reliance on export trade (export trade as \% of GDP) in 1991, 1992 and 1993 was $17.57 \%, 17.37 \%$ and $14.96 \%$ respectively. After the exchange rate reform n 1994 it sharply went up to $21.62 \%$, and then $20.48 \%, 17.67 \%$ and $19.2 \%$ in 1995, 96, 97 respectively. Even with the onslaught of the Asian financial crisis when China's export trade contracted substantially, with a growth rate lower than that of the GDP, yet the reliance remained at a high level (Fig. 15).

Becoming increasingly dependent on export trade, China further internationalized its economic development. However, it also intensified the global economic cycle's impact on its economy. Since then the economic crises in China have become increasingly correlated to external factors.

\section{The Urban and Rural Sectors Jointly Shared the Costs of 1993-1994 Crisis}

The reason that this 7 th crisis was regarded as ending at a "soft-landing" by the mainstream was mainly based on two benchmarks-GDP and 
CPI. It did seem reliable. Yet, What accompanying the "soft-landing" were a whole series of unprecedented enormous costs: a huge number of layoffs of SOE employees, the withdrawal of the government from public services leaving the latter to the private sector, the deterioration in rural governance, the sannong issues, and so on. It would not be objective to neglect the enormous social costs behind the "soft landing".

We believe that the costs of this crisis had been transferred to and shared by both the urban and rural sectors. In particular, this macroeconomic crisis impacted rural economy and peasants' income in many respects. They were not merely the bearer of the crisis costs.

\section{Urban Workers Laid off on Large Scale}

The eruption of this crisis was different from previous ones in that it was not manifested in variations in fixed asset investment level or rate of employment in the society. Rather, it was expressed as a sudden jump into the overheating of regional economies agitated by the Southern Inspection speech by the supreme leader, pushing further the Reform and Opening Up. That was simultaneous to the central government's opening of the three major capital markets as well as the large-scale expansion of money supply. The consequence was a crisis symptomized by three major deficits giving rise to hyperinflation. And under pressure, the policy makers kept their mouths shut regarding the reason for the over-staffing and inefficiency in SOEs: ten years ago the SOEs were given the instruction to absorb young people seeking employments, with the approach of "hiring ten persons with the wages of five", as a measure to deal with the crisis back then. On the contrary, they now reproached the SOEs for low efficiency. From the vantage point of capitalist interests, the government mandated the SOEs to improve efficiency by means of lay-off and down-sizing (Image 5).

This crisis and its handling took place during China's eighth fiveyear plan. Based on statistics, we can find a striking phenomenon during 1991-95 - the emergence of unprecedented high economic and investment growth rates along with an unprecedented low employment 


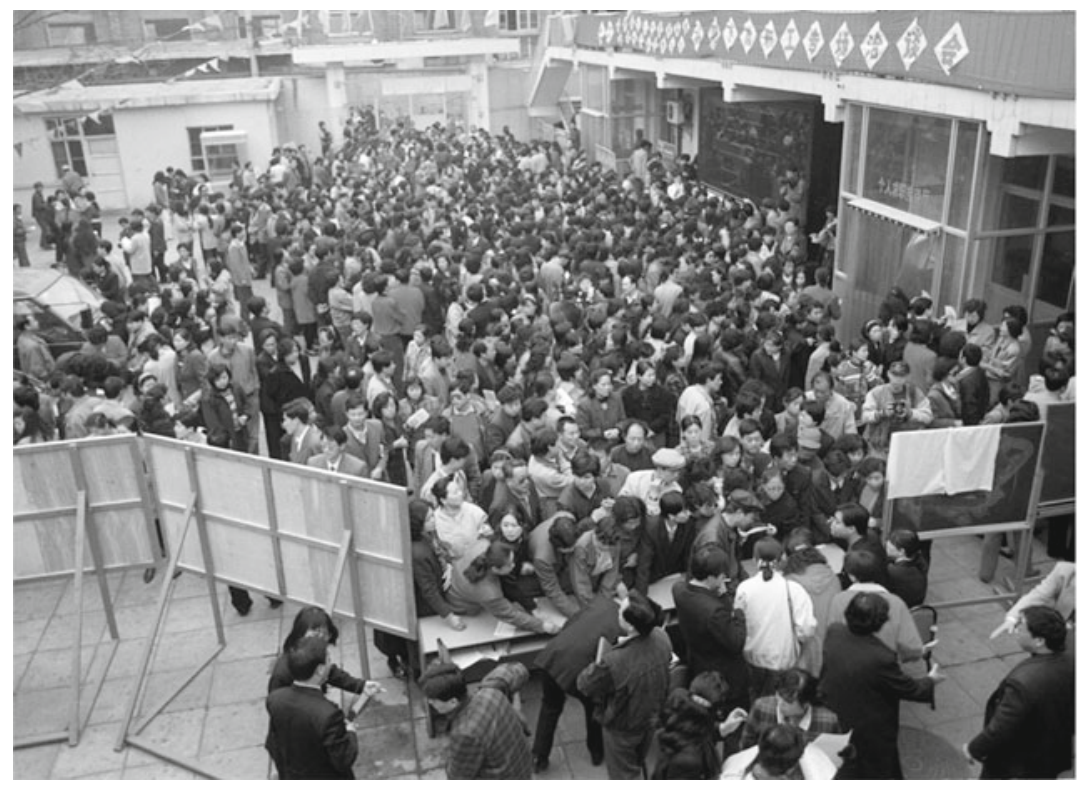

Image 5 In Beijing, close to ten thousand female state-owned enterprise workers over age 35 , who had been laid off or in a semi-unemployed state, participated in the recruitment of a commercial group. Two thousand of them would be hired as salespeople in the group's 100 chain stores. The reemployment of China's older laid-off female workers was raising the concern of the whole society

growth rate. According to Hu Angang's research, during the eighth fiveyear period, the average GDP growth was $11.9 \%$, the highest record up to that point. At the same time, the total investment in fixed assets had an annual growth of $36.1 \%$ on average. Even taking out the impact of CPI, the average yearly growth was still $20.6 \%$. Yet during this period, the annual employment growth was merely $1.3 \%$, much lower than that of all the former five-year plan periods. ${ }^{18}$

In particular, during 1994-1995, there was almost no employment growth in the SOE sector. The other side of the low employment growth was the widespread lay-offs of urban workers. Compared to previous

${ }^{18} \mathrm{Hu}$ Angang (胡鞍钢) “就业: 中国发展的第二号任务” (Employment: The Number 2 Mission of China’s Development), 改革内参 (Internal Reference on Reform), 1997(12). 
crises before the Reform and Opening Up, the state now did not have the possibility to send surplus labor to the countryside as a means to alleviate the unemployment pressure in cities. Moreover, due to serious fiscal deficits, the government retreated from its commitments to the public services such as health care and education, not even providing basic social security. The urban residents painfully bid farewell to the traditional system that had provided social welfare from cradle to grave, similar to those Scandinavian welfare states. They lost their largest social identity advantage compared to their rural counterparts.

In the name of SOE reform, the massive lay-offs, bankruptcies and mergers being forced through during the 1993 crisis marked a new era in the urban sector. The urban workers, used to be members of the urban vested interest blocs, this time had to directly bear the costs of economic crisis caused by a series of events-the expansion of state industrial capital, the concession to local governments and the subsequent frenzied introduction of foreign investments. Since then, the urban interest blocs became diversified. Most importantly, capital has taken absolute dominance over labor.

Since the introduction of the Bankruptcy Law in 1988 till 1993 before the crisis, there had been 940 cases of enterprise bankruptcies. Most of these were small to medium enterprises and collective enterprises. In the year 1994 when the crisis broke out, China finally established in a formal way the status of "capital" in the sense of classical economics. The State Commission for Economics and Trade proposed pilot scheme zones for "optimizing capital structure", and raised the issue of re-settling workers from bankrupt enterprises in Document Number 59 [1994].

By 1997, out of 111 cities that were pilot scheme zones, a total of 16.87 million staff was being "diverted", actually through mergers, bankruptcy and down-sizing. In January 1997, the State Council convened a working meeting in Beijing on the nationwide re-employment of SOE workers. During this year, the State Council and other related departments as well as organizations like All-China Federation of Trade Unions promulgated many documents relating to 
SOE bankruptcy and merger, as well as projects on staff re-employment, boldly and resolutely forcing through this task. ${ }^{19}$

According to a survey on Mianyang Township in Sichuan conducted by the Ministry of Labor, Mianyang, being a national pilot scheme site for "optimizing capital structure" as well as the provincial "two transformations" project [modern enterprise system and flexible market mechanism], had 62 cases of SOE bankruptcy since 1996, with 21,000 workers being laid off, accounting for $7 \%$ of SOE workers in the township. ${ }^{20}$ Another example was a survey conducted by Chinese Textile Trade Union in 1996 on six cities in three provinces. Just under the Xian Textile System there had been 8,940 laid-off workers, 55\% of the staff. Of them, $70 \%$ had no income. In Zhangiiakou, the laid off workers under the textile system had reached $10,500,61.7 \%$ of the total. Some factories even let workers take woolen material from the inventory in lieu of compensation. ${ }^{21}$

When all these became twentieth century history, different theorists gave different assessments. One young scholar pointed out that it was a polarized and exclusive growth while another reputed reform theorist expressed in an implicit way: what China practiced was a "non-populist growth". Although the latter was more widely accepted by the mainstream in the West, the contents of these two formulations were not essentially different.

\section{Marketization and Privatization of Public and Social Services}

Provision of services by public sector usually has the characteristic of "information asymmetry". Among these, medical care and education even have absolute "information asymmetry". They are liable to

\footnotetext{
${ }^{19}$ https://www.wyzxsx.com/Article/Class4/201008/172397.html.

${ }^{20}$ Liu Xiahui (刘霞辉) \& Mo Rong (莫荣) “国有企业改革与职工再就业问题研究” (On SOE Reform and Workers Re-employment), Working Paper.

${ }^{21}$ China Textile Union “救救纺织行业困难职工” (Rescue the Textile Industry Workers in Difficulties), 改革内参 (Internal Reference on Reform), 1996(21).
} 
monopoly by individuals for profiteering if they become commercialized and privatized.

Whichever the political system, so long as the state allows the commercialization of medical care and education where absolute information asymmetry exists, it is inevitable that hospitals, schools and individuals in the related professions would make use of their absolute informationmonopoly positions to reap super profits from clients in disadvantaged positions. Therefore, any normal state would have to provide basic inclusive social services in public sector with a stable fiscal budget support. It should also strictly scrutinize the sources as well as motives of non-public investment in order to protect public interests by maintaining a relatively high ratio of public services.

The simultaneous major deficits in fiscal budget, balance of payments and financial sector in 1993 resulted in the comprehensive marketization reform in 1994 . During this time the government, under the pressure of increasing fiscal deficits arising from the accumulation of foreign debts, was forced to cut budget support to medical care and education (in rural regions in fact a full retreat), thereby prompting the completion of commercialization in these realms. Accompanying this institutional change were a series of problems including unaffordable medical charges and high sales commission on drugs, unregulated education fees, unregulated financing, etc. Moreover, the serious corruption of relevant intellectual groups (medical doctors and teachers) became a chronic ailment.

The problem of the unspoken rule behind these phenomena, generally regarded as social corruption, became even more severe. Many professional practitioners in these fields took abnormally high profit as a matter of course, based on their monopoly on information, and deliberately constructed an open system with intrinsic mechanisms to protect their vested interests. Those officials in the authorities responsible for the institutional provision had intricate connections and relationships among themselves, leaving little room for institutional improvement. Therefore, even though they continued to take up and devour a large portion of public resources, low-cost and inclusive public services became almost impossible. 
Before the reform most of the public services had been provided by workplace units. They were public institutions affiliated to various tiers of the government, including schools, hospitals, agricultural technology stations, cultural centers and so on. In the first few years of reform, the government at one time had increased expenditures on public services, putting education, medical care, poverty alleviation, environmental protection and social welfares as priorities. The proportion of budget expenditure on education as a percentage of GDP was raised from $1.8 \%$ in 1978 to $2.2 \%$ in 1982 . As for medical care, it was raised from 1 to $1.3 \% .^{22}$

However, with fiscal deficits rising, the state adopted a "shrugging off burden" measure similar to reforms in other realms. It shrank the functions it should have been performed, even fully withdrawing from some social services. In addition, both the government departments and workplace units had to increasingly rely on off-budget sources of funds, with the result that it became a common practice for government departments to set up companies, while public faculties would hasten to provide fee-charging services. Hence, urban residents and the peasants had to take increasingly the costs of public services.

The state's target for education expenditure as percentage of GDP was supposed to reach $4 \%$ by the end of the twentieth century. In 1990 , the number was $3.04 \%$, then down to $2.73 \%$ in $1992,2.54 \%$ in 1993 and $2.46 \%$ in 1996 on a declining trend. It was not until 1997 that the decline stopped and it went up slightly to $2.5 \%$ in $1998 .{ }^{23}$

According to regulations, local governments should be responsible for obligatory primary education. Yet when local fiscal capacity failed to pay for the cost, primary education that should have been a public good had to be paid for by the people in the name of reform, with the slogan "people's education run by the people".

The medical care expenses in 1990 had taken up only $2.79 \%$ of GDP in China. By 1997 it declined to $2.45 \%$. Yet according to the

\footnotetext{
${ }^{22}$ Wang Peihua (黄佩华) “中国能用渐进方式改革公共部门吗?” (Can China Reform the Public Sector with a Gradual Approach?), 社会学研究 (Sociological Research), 2009(2).

${ }^{23}$ Wang Xiaohui (王晓辉) “教育财政体制改革应有新思路” (There should be New Ways of Thinking in Reforming Education Expenditures), 改革内参 (Internal Reference on Reform), 1999(22).
} 
minimum standard set up by the state- "everyone enjoys health care"the percentage should not have been lower than $8 \% .^{24}$ The proportion of health care expenditure paid by the citizens relative to total health care expenditure was $23 \%$ in 1980 . By 1990 it went up to $37 \%$, a rise of 14 percentage points in the first decade of reform. By 1999 the proportion became $59 \%$, a rise of 22 percentage points in the second decade. It was a process of state expenditure contraction, while the citizens had to pay more and more. The medical care insurance reform was launched in 1996. However whether in cities or rural regions, the coverage was reduced and the proportion of medical fees to be paid by individuals rose up. There had been doubts and comments from international specialists and international trade unions regarding the design of individual accounts in medical insurance, similar to the pension fund system. ${ }^{25}$

\section{Local Government Transferred the Governance Costs to Villages; Serious Social Contradictions}

Since the beginning of the Reform and Opening Up in the 1980s, China had undergone two fiscal system reforms, first the 1984 "fiscal responsibility by tiers" in 1984 and second the "tax division" in 1994. Both of these reforms which embodied the policy principle of "shrugging off burden" resulted in adverse impacts on rural governance.

At the same time as the central government and various tiers of local governments implemented the fiscal responsibility in 1984, the policy of "self-financing" among the two-tier rural administration-county and village-was launched as part of the reform. The people's communes were disbanded to set up counties while the production brigades became villages. As a result, the administration costs to be paid by the villages to maintain the two tiers of superstructure substantially increased. In addition, the funding for public services in rural regions had to be provided by the grass-root (mostly the peasants).

\footnotetext{
${ }^{24}$ Zhou Yanling (周雁翎), “差异悬殊: 中国卫生保健事业面临严峻挑战” (Wide Differential: China’s Medical Care Profession Facing Severe Challenge), 中国改革 (China Reform), 2002(4). ${ }^{25}$ Liu Haiying (刘海英) “我们到底能做什么” (What In Fact Can We Do?), 中国改革 (China Reform), 2002(4).
} 
By the time of the 1994 tax division reform, every tier of government attempted to shrug off its responsibility of building local infrastructure and providing public services to the next tier below. Most of the local budgets were spent on infrastructure and public administrations. ${ }^{26}$ At the levels of county and village, particularly in central and western regions, the problem of asymmetry between financial power and administrative power emerged. Most local governments had only sufficient financial power to maintain the very basic administration, with no capacity to make improvements to the society, thus deviating from the principle of public finance. ${ }^{27}$ The central government exerted tighter grip on regional finance. Locally disposable financial capacity rapidly contracted. A governmental organization would in nature tend to protect its self-interest by "taking the financial power from lower tiers while pushing down the expenditures". After tier by tier holdbacks, the grassroot level public bodies at counties and villages, the lowest end of the administrative hierarchy, got trapped in financial quagmire.

Under normal circumstances, the consequence of fiscal system reform with tier-by-tier "offloading burden downward" would not be visible. However, when there was crisis giving rise to austerity measures, the costly superstructure designed according to the imagination of political modernization and built over a peasant economy with little extractable surplus to support it would inevitably result in additional burden on the peasants scattered in rural regions. Hence, the rural regions became the hotspots throughout the entire 1990s with increasing cases of mass protests at larger and larger scale, mostly against excessive tax and levies, illegal expropriation of land, disruption to the land responsibility contracts etc. ${ }^{28}$

${ }^{26} \mathrm{Li}$ Chenjie (李晨婕) \& Wen Tiejun (温铁军) “宏观经济波动与我国集体林权制度改革” (Macro-economic Fluctuations and China's Collective Forestry Rights System Reform), 中国软 科学 (China Soft Science), 2009(6).

${ }^{27}$ Chen Xiwen (陈锡文), Han Jun (韩俊) \& Z Zhao Yang (赵阳) “中国农村公共财政制度 研究” (Study on Rural Public Finance System in China), 宏观经济研究 (Macro-economic Research), 2005(5).

${ }^{28}$ Dong Xiaodan 董䈗丹 \& Wen Tiejun “宏观经济波动与农村治理危机” (Macro-economic Fluctuations and the Crisis of Rural Governance), 管理世界(Management World), 2008(9). 


\section{Financial Capital Alienated from Physical Industries}

Of the so called "sixteen iron and blood articles," the central government macro-regulation measures in response to the crisis in 1993, more than a half were concerned with financial policies. The ailment of economic overheating created by bureaucrat profiteering companies and related government bodies had to be cured with the medication of nationwide austerity measures. The overall credit-tightening damaged the overall balance in credit. Restricted credits among some regions largely reduced the money circulation rate. It hurt to a large extent mostly the small and medium non-SOE enterprises, while the impact on large SOEs was insignificant. The most striking phenomenon was the big differential between the official and market interest rates. In the summer of 1993, bank loan interest rates along the coast were between 10 and $16 \%$ (annual rate up to 20\%) while the market rates reached 20 $35 \% .{ }^{29}$ Long-term financial capital scarcity would naturally push up the interest rate. Economic overheating was like adding fuel to the fire. Yet under macro-regulation it took a twist. Financial capital became alienated from real industries-the allocation of financial resource in the 1990s increasingly drifted away from the real economy, swarming the stock market and real estate market in seeking profits. Virtue capital started to take shape in China. It transmuted into a means to share the allocation of profits, rather than creating real profit. Financial capital would depart from realms with lower liquidity and lesser odds for speculative profitability. The consequence is the trend of "financial exclusion" that developing countries in general would experience in their course of development.

During this period, it was precisely because of the trend of financial exclusion that the natural environment suffered disastrous consequences. The situation of forestry in mountainous regions was a typical example.

${ }^{29}$ https://zhidao.baidu.com/question/41628982.htm1?si=9. 


\section{Box 9: Predicament of Forestry in the 1990s}

Since forestry has a long production cycle, implying a slow turnover of funds, long investment maturity and high risks, the macro-economic institutional changes had a dampening effect on forestry as well as the reform and development of forestry districts. Given the structural adjustments in national economy, industrial capital was set to transmute into financial capital seeking higher profitability. Eventually it would be drawn to the monopolized financial sector. Whether the forestry ownership was scattered or concentrated would not be a matter of concern to financial capital. Therefore forestry found it hard to draw investments from financial capital in this period. In 1993, in the loess plateau regions like Shanxi and Shaanxi where even the local governments were entrapped in extreme poverty, there were cases where usage rights of barren land had been auctioned off at a negligible price. Then in August 1995, the Ministry of Forestry in conjunction with the National Reform Commission promulgated the document “林业经济体制改革总体纲 要” (Comprehensive Outline of Forestry Economic Reform), consolidating the direction of forestry rights marketization as mandated by the central policy. It clearly specified the goal of creating a market for the living stumpage in forest plantation. Forest assets should be liquidated through various means such as biding, auction, renting, mortgage or consignment.

The pilot scheme sites started with auctioning barren land suitable for reforestation and transferring forestry resource and further developed into the circulation of forestry usage right.

In view of the fact that China was at the industrial expansion phase back then, the capacity for capital to integrate with other essential factors of production was strengthened. Therefore this marketization of forestry rights, referred to as "the second forestry reform," resulted in the resources of the mountain regions being concentrated in the hands of well off households and cadres to form economies of scale. The goal was to attract external funds to realize the capitalization of local resources in order to stimulate economic growth in the mountain regions.

After the second forestry reform the facts from different places stated clearly that the related benefits were mainly taken by well-off households, cadres or tycoons that were already quite well-endowed in capital whereas the resource owners could attain the social average return for production 
factors by their participation in the social division of labor. However the negative externality arising from this institutional reform was embodied in higher social contradictions and the worsening predicament of the country's forestry, indirectly causing environmental disasters.

The social contradictions became intensified because the outcomes of the reform were not consistent with the intention of promoting the development of collective forestry land to increase peasant incomes. No matter how the property right was transformed, the concentration of resources led to the deprivation of a part of the right of mountain people to make a living from the resources proximal to their settlement.

The worsening predicament for forestry was expressed as follows:

On one hand China had to pay other countries to import large quantity of wood and other forestry products (Zhang Daohui 2001). Yet on the other hand the collective forestry regions had large areas of barren land. After the tax division system reform in mid-1990s, forestry tax was raised further and the total levy of tax and charges in forestry operation amounted to more than $51 \%$ of the selling price of timber. In addition there were all kinds of fees collected by various tiers of governments and various tiers of forestry departments during the production and distribution. The higher the overall tax and charges the lower the purchase price became. Furthermore, there were widespread cases of sabotage, illegal logging as well as bribery and corruptions, indirectly causing destruction to the environment. The high levies were ultimately transferred to the peasants as producers of forestry products. As a result, large areas of forestry land were deserted.

Source: materials collected by the author's research team

\section{Fundamental Change in the Mechanism for Capitalization of Land Resource}

In the first round of "land enclosures", arable land had been recklessly appropriated mainly by rural enterprises, disrupting the overall plan of national construction. On 21 March 1986, the document issued by CPC Central Committee and the State Council "Notice on Strengthening Land Management and Stopping Misappropriation of Arable Land" clearly pointed out that: "the phenomena of rural enterprises and residential properties in rural regions recklessly occupying arable land is 
conspicuous. If the situation continues it would lead to serious bad consequence to national construction and the livelihood of the people, endangering future generations." One aspect that should be noted was that the profits generated from appropriating arable land for industrial use within rural communities had mainly gone to the collectives while the government could barely take a share. Yet the latter had to take the responsibility for "food security". In late 1980s the central government started to request a stricter control on converting arable land to non-agricultural purposes, and gradually took back the power to approve converting arable land for industrial and commercial use. That notice issued on 21 March 1986 had requested regional governments to comprehensively investigate illegal use of arable land and not to grant lower-tier administrative bodies the approval authority. In the same year the "Land Management Law" was also introduced to confirm the state's authority on converting land use to non-agricultural purposes. In 1988, the State Bureau of Land Administration was set up to exercise full authority in this regard.

However, at the same time when this authority on approving land use was taken by the government which was characterized by corporatism, the nature of land as a commodity was also been gradually established. In 1988, the Amendment to the Constitution of the People's Republic of China stipulated that the land use right would be transferrable in accordance with legal regulations, thus officially ushering in the compensable use of land in China. On 19 May, 1990, the State Council announced the implementation of "Provisional Regulations on the Transfer and Conveyance of the Right to the Use of State-owned Land in Township", providing clear regulations on the transfer, renting and mortgage of land usage right. Land was in practice endowed with the attribute of commodity. That fundamentally changed the nature and mechanism of land capitalization. In the 1980s land was used for productive purpose by the self-initiated development of grass-root rural enterprises i.e. "building enterprise with land". In the 1990s, however, land became a means for local governments to generate fiscal revenues to cover the inelastic expenditures, i.e. "cashing in land". Its nature changed from productive to consumptive. Cashing in land became the fastest way to make money for the local governments. 


\section{Box 10: Real Estate Development and Regional Expropriation of Land in the "Second Land Enclosure"}

In 1992, the liberalization of real estate pricing instantly prompted a boom. The growth in completed real estate investment in 1992 was $117.42 \%$ and the profit growth was $140.39 \%$. In 1993, these two indicators were $164.98 \%$ and $145.47 \%$ respectively. The local governments and real estate development related sectors all enjoyed a hefty share of profit from this booming. The enormous monetary capital of stateowned monopoly banks was instrumental to the formation of capital land rent and differential rent since 1994 by way of real estate development through the transfers of state-owned land use rights and ownership. With the financial sector acting as an agent of capital oversupply, the land rent was embodied in the high return rate from real estate investments, the profits of which were devoured by the developers. Through this movement of stripping off the state ownership of land (the essence of the frenzy in granting such permissions), giving rise to the real estate investment craze, by which the nouveau riche class in China made their second bucket of gold.

Yet, it was precisely these high profits generated by real estate development (in essence land rent) that stimulated the economic prosperity in China during 1993-1995. The total operating incomes from real estate development in 1992 and 1993 reached 52.86 and 113.59 billion yuan respectively, higher than the previous year by $86.1 \%$ and $114.9 \%$, while the revenues from providing construction land reached 4.27 and 8.39 billion yuan, higher than the previous year by $177.9 \%$ and $96.4 \%$ respectively.

The development zone craze and real estate craze in early 1990s brought on the second peak of land enclosure. Since 1992, the total constructed area skyrocketed to the peak of 271,000 hectares by 1993 . In 1992 and 1993, the total area of real estate developments grew by $174.96 \%$ and $96.61 \%$ respectively from the previous year (Source: China Real Estate Market Yearbook 1996).

Excerpts from: Yang Shuai (杨帅) \& Wen Tiejun “宏观经济波动、 财税体制变迁与三次圈地运动” (Macro-economics, Taxation Institutional Transition and Three Rounds of Land Enclosure), 管理世界 (Management World), 2010(4). 
The second round of land enclosure that was initiated by the local governments was very unlike the first as it involved different agents and lasted longer. During 1994-1998, with year-over-year decline in the economic growth rate and the central government sparing no efforts to suppress land enclosure, the arable land reduction per year still averaged at 215,000 hectares (since the data for 1996 was not available, the computation was based on the average of 1994, 95, 97 and 98).

The peak of land enclosure during 1992-1995 may generally be interpreted as the institutional costs of implementing institutional transitions in order to resolve the 1989-1991 economic crisis. During this period, the large amount of expanded money supply was able to be absorbed within a short span of time by large scale capitalization of land. That in turn helped revive a high economic growth. The central government under the burden of taking the ultimate liabilities for domestic and foreign debts was able to leap out of the predicament of 1993 in which the volume of three major deficits had been larger than China's total GDP.

It was somewhat similar to the situation in the 1980s in which large scale land enclosure had prompted high economic growth. Yet the actual mechanism and channels of capitalization were very different. In the 1980s it was because of the rise of rural enterprises that land was appropriated. Land required an integration with other physical assets of enterprises to become a material "asset" in industry or commerce. The added value of land was realized through business operations. Yet by early 1990s, land itself became the object of business. Simply by means of land development or entitlement transfer, it was possible to attain much higher profits than in the stage of "building enterprises with land" in the 1980s. For example, in Xietang township in Suzhou, thanks to the Suzhou Industrial Park, the local government cashed in 98.8687 million yuan in land leasing during 1992-1999. Taking out 8.866 million submitted to the state and 266.1 thousand as balance, the rest was all spent as public expenditures in the town. 11.1671 million yuan was allotted to the villages at lower tier, 2.3816 million for agricultural expenses, 4.9189 million for culture and health care, 6.8261 million for administration, 13.881 million for public services, 4.4929 
million for hygiene, 20.569 million for development, 20.25 million to external investments, 5 million others. ${ }^{30}$

It also meant that the interests-structure inside government corporatism underwent changes. Alienated from localized industrial capital, the local governments generally relied less and less on sharing the added value of localized industrial capital, but instead welcomed investments from outside that did not have to take the responsibilities for local community welfare.

Given that the mechanism of land capitalization and the agents of land capitalization had both undergone changes, the allocation of added value generated from converting arable land to non-agricultural purposes also showed corresponding changes.

First, the village collectives no longer played a leading role in land capitalization. Also, after the change of land use, the revenues generated were no longer relevant to the collective accumulation for local members. Instead, after a one-time compensation for expropriation, the peasants lost connection to their land.

On one hand, when the local governments exercised its monopoly power granted by the state over arable land conversion, they obtained the monopoly gains generated from the added value of the land. During the process of land expropriation, given that the collective economy was in reality no longer the property right owner, the government was able to exercise direct control over the administrative and party organizations at the village level to largely reduce the transaction costs in acquiring the land. According to a survey by Wen Tiejun and Zhu Shouyin in 1996, the peasants would only get $5-10 \%$ of the revenues; village collective economic organizations would have $25-30 \%$; and $60-70 \%$ would go to the government and various authorities. And the portion that went to the village collective organizations would usually be controlled by the village cadres. ${ }^{31}$

\footnotetext{
${ }^{30}$ Xietong Town Chronicle Editing Committee, 斜塘镇志 (Xietong Town Chronicle). Beijing Local History Publishing, 2001.

${ }^{31}$ WenTiejun \& Zhu Shouyin (朱守银) “政府资本原始积累与土地“农转非” (Government Primitive Accumulation of Capital and Converting Land from cultivation to non-agricultural purposes), 管理世界 (Management World), 1996(5).
} 
On the other hand, the separation of government and enterprise starting in 1992 and the rural enterprises ownership reform in mid and late 1990s in effect transformed the rural enterprise from being the vehicles responsible for communal welfares and maximum employment in the collective into industrial entities simply seeking profit maximization. The collective enterprises had relied on the collective resources to complete the capital accumulation. Then by means of institutional changes the enterprises became the sole and exclusive owners of the assets generated. It was highly similar to the process in which the enterprises under whole people ownership had completed the accumulation relying on state power and then during its reform the ownership was gradually altered and these enterprises became the sole owners of the assets. Moreover, the industrial capital brought in by local governments to various development zones has never established any direct connection to local welfare as collective rural enterprises once did.

Second, the one-time compensation was being deducted tier by tier before it finally arrived at the hands of peasants. Moreover, the sharing of profits from land development was also extremely uneven. As a comparison, in the 1980s when villages initiated land appropriation on their own to establish productive enterprises, the profits generated from land capitalization had stayed within the village to a large extent, and been spent on community welfare and agricultural expenses. At the same time it had stimulated non-agricultural employment and raised cash income for the peasants. In the 1990s, however, the profits generated from cashing in the land were mainly shared between the local governments as well as the industrial capital. In the 1990s, some local governments proposed the slogan of "generating wealth and making the towns prosperous through land". However, in practice, some surveys showed that in some counties the local governments relied on land leasing for $20-30 \%$ of their finance. In some towns, more than $80 \%$ of off-budget revenues came from land leasing. While land and capital, two scarce factors, were both leaving agriculture, the proportion of agricultural population moving to towns was consistently declining as the land price was rising (ibid.).

The growth rates of peasant income and consumption in the 1990 s were significantly lower than in the 1980s when domestic demand 
was the main thrust of economic growth. From a long-term perspective, it gradually led to a serious shortfall in general domestic demand during the 1990s since the peasants comprised the majority of the population. Therefore the national economy shifted towards a greater dependence on export. This important shift did not suit the strategic needs of the time when China's industrial capital was in a phase of rapid expansion. However, the short-sightedness created by the symbiosis of government corporatism and localized industrial capital resulted in their blindly going along with the economic cycle into the next phase that entailed even higher institutional risks.

\section{The Positive and Negative Impacts of Crisis Management on the Sannong}

On the positive side, at the same time when urban and rural sectors both had to bear the costs of this crisis, the rising staple grain prices did contribute to raising peasants' income level. Also, since the peasants could now buy staple food with cash in cities, they left their home villages and swarmed the urban sector to seek employment with the rapid expansion of land development.

Because of the higher demand on coarse grain due to the rising population of migrant peasant workers, there had been a shortage of low quality grain in 1993. The policy makers became worried that inflation might be incurred in case of inadequate grain supply. To secure the supply, the government launched various projects during 1994-1996 with a larger financial support to agriculture. The purchase prices of grain were twice raised by a large amount, with an accumulated increase of $105 \%$. The agricultural income was consistently growing. And China was able to realize its target of 1 trillion catties production in 1996, four years ahead of the scheduled year $2000 .^{32}$

Yet there was also negative impact. With the eruption of the 1997 Asian financial crisis, the economy went on a downward cycle. The urban demand for grain declined while total population growth remained at the

\footnotetext{
${ }^{32}$ Wen Tiejun “中国粮食供给周期与价格比较分析” (Comparative Analysis of China's Food Grain Supply Cycle and Prices), 中国农村观察 (Rural China Survey), 2003(3).
} 
expected rate. That meant, in terms of population number and demographic structure, the consumption of grain could not possibly expand to the 2000 level four years ahead of time. The problem of grain oversupply emerged. As the economy fell into depression, the prices of grain and the cost-effectiveness of grain production both declined.

Chinese agriculture increasingly showed signs of degeneration in the late 1990s.

In summary, Chinese economy started in 1992 to change from being industry-oriented to capital-oriented. It led to economic revival, immediately followed by a surge. With this stimulation, an increasing number of peasants went to the cities for employment. Their labor and service incomes went up (even though the financial crisis later in 1997 would lead to a new cycle of agricultural employment growth with the reverse-urbanization). A survey found that since the 1990s China has a clear cyclical expansion and contraction in the primary industry. The first cycle lasted from 1991 to 1996, with the agricultural employment of 390.98 million in 1991 down to 348.2 million in 1996 , a reduction by almost $10.94 \% .{ }^{33}$

In any case, this crisis marked the transition and watershed from endogenous economic crisis to exogenous (imported) crisis in China. It was a time in which the industrial capital in China was approaching a state of overcapacity while the financial capital was expanding rapidly and increasingly alienated from the former. Moreover, it was a time when China began to transform into an export-driven economy, thus becoming increasingly susceptible to international economic cycles.

The costs of this crisis were borne by both the rural and urban sectors. The institutional condition of collectivization was no longer available for a complete transfer of the costs to the rural sector. Despite the official announcement of a "soft-landing," both the urban and rural residents suffered hard from it. In the urban sector, an astronomical number of workers were laid off while the villages saw an intensifying social contradiction expressed as protests against heavy tax and levies as well

\footnotetext{
${ }^{33}$ Xie Maoshi (谢茂拾), Cai Zexiang (蔡则祥) \& Wang Haiyan (黄海艳) “金融危机影响下 农业就业的困境与新出路” (Predicaments and Solutions of Agricultural Employment under the Impact of Financial Crisis), 中国发展观察(China Development Observation), 2009(11).
} 
as rampant land expropriation. In both cases the costs of the crisis were expressed as an increasing number of mass protest incidents. At the same time, attempting to resolve the fiscal crisis, the government continued to retreat from the public services provision. As a consequence, urban citizens and the peasants had to bear most of the costs and pay a higher price for the services.

Open Access This chapter is licensed under the terms of the Creative Commons Attribution-NonCommercial-NoDerivatives 4.0 International License (http://creativecommons.org/licenses/by-nc-nd/4.0/), which permits any noncommercial use, sharing, distribution and reproduction in any medium or format, as long as you give appropriate credit to the original author(s) and the source, provide a link to the Creative Commons license and indicate if you modified the licensed material. You do not have permission under this license to share adapted material derived from this chapter or parts of it.

The images or other third party material in this chapter are included in the chapter's Creative Commons license, unless indicated otherwise in a credit line to the material. If material is not included in the chapter's Creative Commons license and your intended use is not permitted by statutory regulation or exceeds the permitted use, you will need to obtain permission directly from the copyright holder. 